\title{
System Simulation Models
}

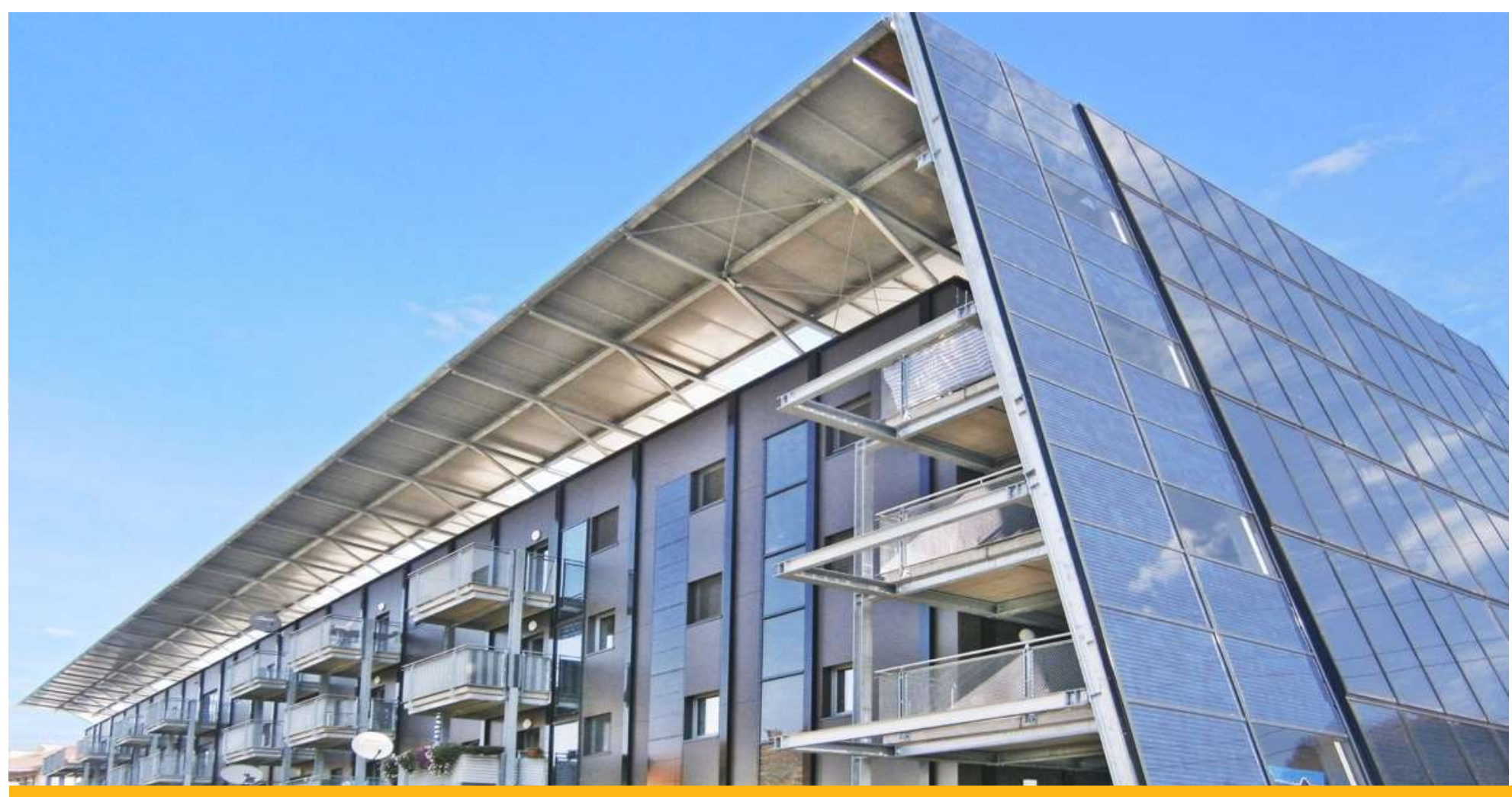

IEA SHC TASK 56 | Building Integrated Solar Envelope Systems for HVAC and Lighting 


\title{
System Simulation Models
}

\author{
Deliverable DC.1
}

Authors: Ochs Fabian, Magni Mara, Bonato Paolo, D’Antoni Matteo, Geisler-Moroder David, Hauer Martin, de Vries Samuel, Loonen Roel

April, 2020

DC.1, DOI: 10.18777/ieashc-task56-2020-0004

The contents of this report do not necessarily reflect the viewpoints or policies of the International Energy Agency (IEA) or its member countries, the IEA Solar Heating and Cooling Technology Collaboration Programme (SHC TCP) members or the participating researchers. 


\section{IEA Solar Heating and Cooling Technology Collaboration Programme (IEA SHC)}

The Solar Heating and Cooling Technology Collaboration Programme was founded in 1977 as one of the first multilateral technology initiatives ("Implementing Agreements") of the International Energy Agency. Its mission is "To enhance collective knowledge and application of solar heating and cooling through international collaboration to reach the goal set in the vision of solar thermal energy meeting $50 \%$ of low temperature heating and cooling demand by 2050."

The members of the IEA SHC collaborate on projects (referred to as Tasks) in the field of research, development, demonstration (RD\&D), and test methods for solar thermal energy and solar buildings.

Research topics and the associated Tasks in parenthesis include:

- $\quad$ Solar Space Heating and Water Heating (Tasks 14, 19, 26, 44, 54)

- Solar Cooling (Tasks 25, 38, 48, 53)

- Solar Heat for Industrial or Agricultural Processes (Tasks 29, 33, 49, 62, 64)

- Solar District Heating (Tasks 7, 45, 55)

- Solar Buildings/Architecture/Urban Planning (Tasks 8, 11, 12, 13, 20, 22, 23, 28, 37, 40, 41, 47, 51, 52, 56, $59,63)$

- $\quad$ Solar Thermal \& PV (Tasks 16, 35, 60)

- Daylighting/Lighting (Tasks 21, 31, 50,61)

- Materials/Components for Solar Heating and Cooling (Tasks 2, 3, 6, 10, 18, 27, 39)

- $\quad$ Standards, Certification, and Test Methods (Tasks 14, 24, 34, 43, 57)

- $\quad$ Resource Assessment (Tasks 1, 4, 5, 9, 17, 36, 46)

- Storage of Solar Heat (Tasks 7, 32, 42, 58)

In addition to our Task work, other activities of the IEA SHC include our:

$>$ International Conference on Solar Heating and Cooling for Buildings and Industry

$>$ SHC Solar Academy

$>$ Solar Heat Worldwide annual statics report

$>$ Collaboration with solar thermal trade associations

\section{Country Members}

\section{Australia}

Austria

Belgium

Canada

China

Denmark

European Commission

\section{Sponsor Members}

European Copper Institute International Solar Energy Society EACREEE

\section{France}

Germany

Italy

Netherlands

Norway

Portugal

Slovakia

\section{ECREEE}

RCREEE

SACREEE
South Africa

Spain

Sweden

Switzerland

Turkey

United Kingdom

For more information on the IEA SHC work, including many free publications, please visit www.iea-shc.org 


\section{Contents}

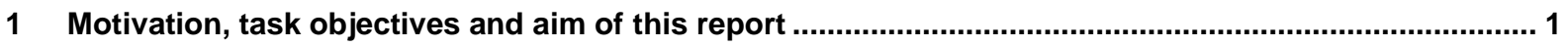

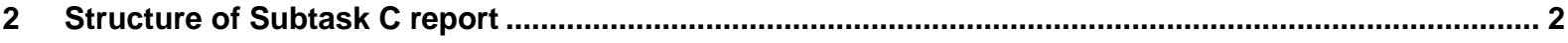

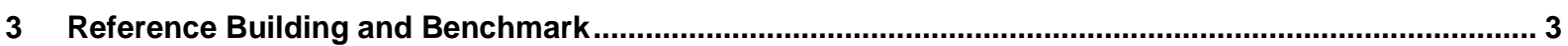

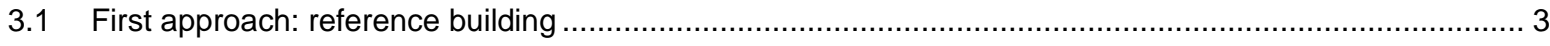

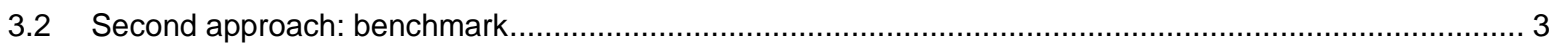

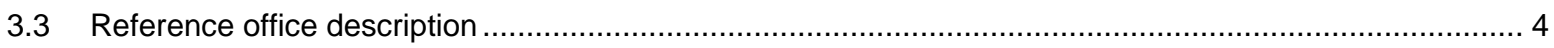

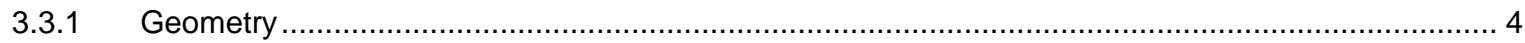

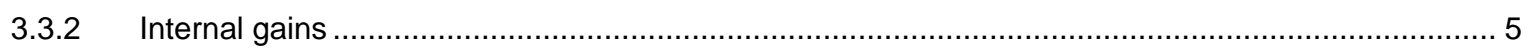

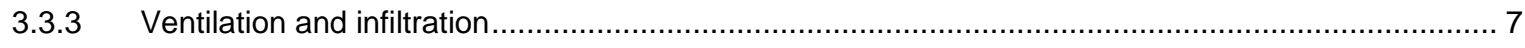

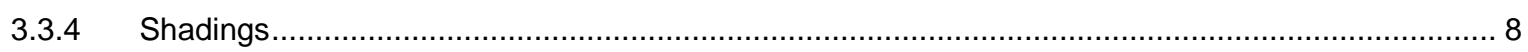

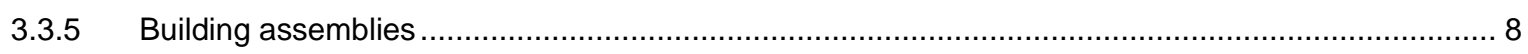

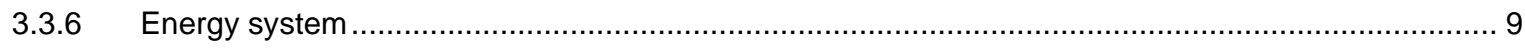

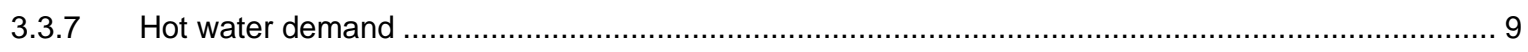

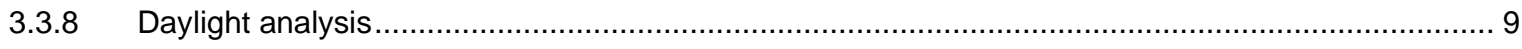

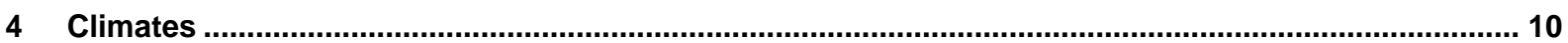

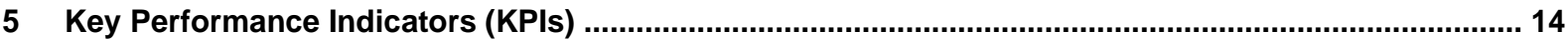

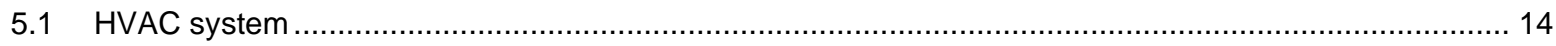

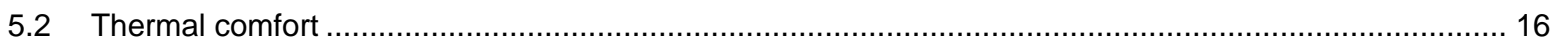

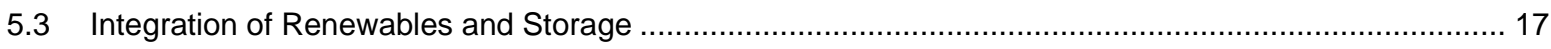

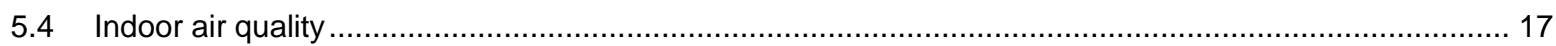

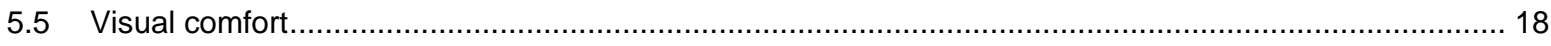

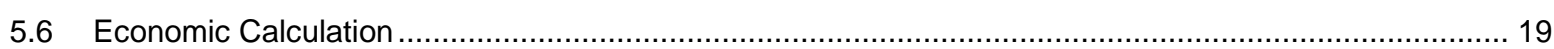

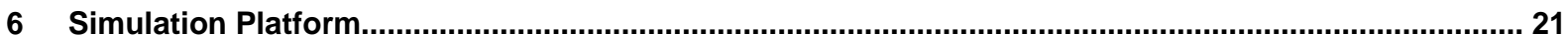

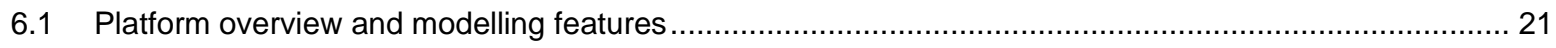

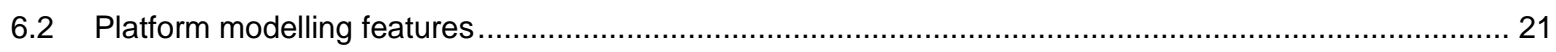

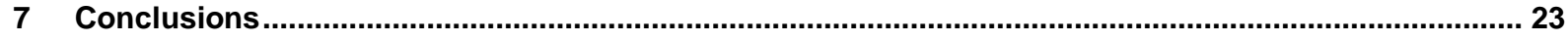

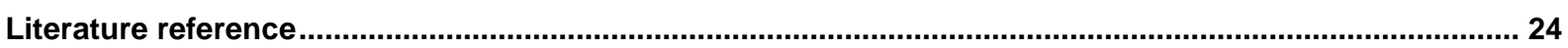

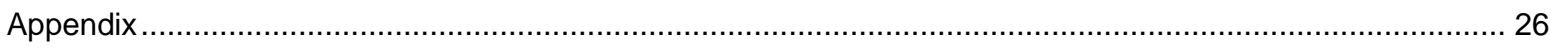

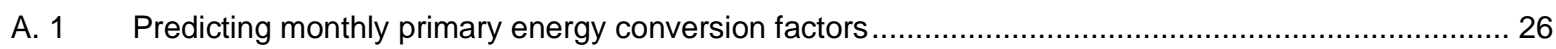

A. 2 Detailed properties of the windows assemblies used in the reference office building ........................ 28 
Building Integrated Solar Envelope Systems for HVAC and Lighting includes a broad variety of technologies. Different "Solar Envelope" solutions for office and residential buildings are investigated and evaluated by means of building and system simulation. Detailed technical/economic analysis will be carried out in order to assess the impact of the integration of the solar envelope components for different buildings in different climates.

Models for these technologies shall allow to develop and optimize control strategies for coupled control of indoor air quality, thermal and visual comfort (lighting) considering optimal energy performance.

We can distinguish Solar Envelope Systems depending on technology, applications and building types.

- Technology:

- lighting / daylighting / shading / glare protection;

- HVAC (heating, cooling, ventilation);

- renewables (electricity, heat).

- $\quad$ Application / Building type:

- non-residential (Office, school, hotel, etc.);

○ residential (Single-Family House (SFH), Multi-Family House (MFH)).

The investigations carried out in the framework of the IEA SHC Task 56 are focused on:

- The determination of the performance of different active heating, cooling and ventilation technologies as well as daylight/shading devices as part of the façade;

- The optimization of the control of these systems with the aim to improve the performances.

Thermal and visual comfort has to be proven for each solution and it is a prerequisite.

The focus for office buildings is daylighting and artificial lighting systems, cooling (and dehumidification) which are in most climates more relevant than heating. Contrariwise, for residential buildings, in particular multi-family houses (MFH) the focus is renovation. Hence, most relevant are ventilation and (renewable) heating/cooling and domestic hot water (DHW) preparation systems, based on façade integrated solar thermal and/or Photovoltaic panel (PV) or Photovoltaic Thermal panel (PVT) systems combined with heat pumps.

Thus, solar envelopes might involve passive elements (i.e. shading, daylight control) and/or active elements (BIPV, BIST, BIPVT). Façades with elements for daylighting/shading, glare protection (solar gains, artificial light) are mainly applied in non-residential buildings and are able to:

- $\quad$ Guarantee visual comfort (while thermal comfort is maintained);

- Increase daylight use;

- Enable primary energy savings (by means of reducing heating demand and cooling demand).

Façades with active elements (i.e. Solar Thermal (ST), Building Integrated Solar Thermal (BIST), PVT or Heat Pump (HP) and/or Heat Recovery Ventilation/Energy Recovery Ventilation (HRV/ERV) coupled with PV, Building Integrated Photovoltaic (BIPV)) for heating/cooling/ventilation can be applied in both residential and non-residential buildings in order to guarantee:

- Thermal comfort and provide indoor air quality;

- Allow for primary energy savings (reduction of heating and cooling demand as well as maximization of renewable energy use).

The objectives of daylighting simulations for non-residential buildings in IEA SHC Task 56 are:

- Investigation of the visual comfort (e.g. glare protection);

- Studying solutions that maximize daylight use and reduce artificial lighting demand while maintaining visual comfort;

- $\quad$ minimization of (heating and) cooling loads and energy consumption;

- Control optimization. 
There is a clear need to understand the influence of the daylighting strategy on the heating and cooling demands and loads. However, usually there is no need to investigate the influence of the daylighting technology on the HVAC system.

The objectives of building and HVAC simulations in both residential and non-residential buildings are:

- Determination of the performance of the building and its HVAC system by means of an annual simulation, (i.e. the determination of heating demand (HD), cooling demand (CD), efficiency/COP of HVAC, use of renewables);

- $\quad$ To correctly size the HVAC system;

- Investigation and optimization of thermal and visual comfort and indoor air quality;

- Optimization of the control strategy for enhancing comfort and air quality while minimizing energy use.

The heating demand (HD) and cooling demand (CD) as well as heating load (HL) and cooling load (CL) are influenced by the daylighting system in terms of internal gains. However, usually, there is no need for feedback from daylight control to HVAC control and vice versa (i.e. as nobody would accept glare just for improving the COP of the heat pump). Therefore, in most cases coupling of daylighting and HVAC simulation is not necessary. During the design process of a building, daylighting control will have first priority and will not be influenced by the HVAC system (i.e. there is only influence in one direction and the HVAC simulation can be done after the daylight simulation).

Remark: The detailed determination of thermal and visual comfort might require geometrically correct representation of a room including furniture and occupants. Furthermore, a detailed and geometrically correct representation of the heat (and/or cold) emission system and shading/daylight system might be required. For a realistic representation, a detailed calculation of the radiative heat exchange and of the flow field might be required. Such calculations are usually steady state and are not coupled with the heat generation system and are out of the scope of this report.

\section{Structure of Subtask C report}

Different approaches for investigating Solar Envelope Systems are required for residential and office buildings. This report has the aims to describe the different methods used for non-residential (i.e. office) and residential buildings and to give comprehensive information about the reference buildings and HVAC systems used in IEA SHC Task 56.

This report DC.1 provides some general information about benchmarks, the simulation models of the reference buildings as well as reference locations and climate analysis and finally Key Performance Indicators (KPIs). Additionally, an overview on the features of different simulation platforms is given.

Based on this, the Report DC.2 documents the simulation results and consists of two parts:

- $\quad$ Part A presents the simulation results of the office reference building;

- Part B describes the approach for residential buildings. Two examples are described in detail following different approaches.

In Deliverable DC.3, guidelines are provided based on the simulation results.

Deliverable DC.4 will provide monitoring results of demonstration buildings 


\section{Reference Building and Benchmark}

\subsection{First approach: reference building}

A common reference building is useful to compare different technologies including the influence of different climates. Resulting primary energy consumption of a certain technology and control strategy can be directly compared with those of other solutions. A common reference building needs a detailed description of:

- $\quad$ Geometry (size, glazing ratio, orientation, ground coupling, etc.)

- Building energy standard (envelope quality, air-tightness, etc.)

- Location

- Usage (occupation profile, internal gains, ventilation and shading)

- Set point temperature

- Heating (operative temperature)

- Cooling (operative temperature)

- Dehumidification (absolute humidity)

- Ventilation/infiltration:

- air tightness and window ventilation;

- mechanical ventilation rate / heat recovery effectiveness;

- night ventilation (volume flow and control settings and set points);

- $\quad$ Shading (reduction factor and control settings and set points).

Such a building can be:

- Real (i.e. existing) which is more realistic and easier to motivate or

- Generic/simplified/generalized which is easier to setup, to communicate and also it is more suitable for model exchange, platform independence etc.

Based on the description it must be possible to reproduce the results and to develop the model for different climates, with different technologies and on different simulation platforms. Hence, such a model cannot be very complex and time consuming to set it up. Once the simulation models are calibrated, input errors can be excluded and different solutions can be compared against the common reference case for a given climate in terms of primary energy savings and $\mathrm{CO}_{2}$-emission reduction.

In case of office buildings as an example of non-residential buildings in order to investigate thermal and visual comfort and façade integrated decentral heating and cooling solutions and or daylighting systems, the reference model can consist of one typical office cell (one thermal zone) only. Offices look very similar all around the world. The extrapolation of the results to the entire building is possible e.g. as the sum of the performance of single simulations of the cell in e.g. different orientations and assuming loads and gains for the traffic zones. Investigations on integration of Renewable Energy (RE) in central ventilation, heating and cooling systems is limited with the office cell approach. A further disadvantage is the difficulty to extrapolate the results to the entire building even in case of decentral applications. However, with the focus on daylighting systems, the detailed investigation on office cell level is required.

The common reference building (test cell) approach is used for the non-residential (office) buildings (see section 3.3 for the description of the office building).

\subsection{Second approach: benchmark}

In the residential sector, application of solar façades is more relevant for multi-family buildings (with relative small available roof area) than for single-family houses (with relevant roof area with respect to treated area). The reference building approach cannot be applied easily in residential multi-family buildings because usually, each building is individual (geometry, floor plan, number of floors, heated/unheated cellar, etc.). Furthermore, for residential buildings, the focus is the envelope, HVAC performance and (façade integrated) RE system. Providing high thermal comfort and indoor air quality is a prerequisite (that has to be proven for each technology). Visual comfort (daylighting and glare) is usually not relevant in residential buildings. Depending on the investigated technology, usually either a flat or the entire building has to be considered and it is not trivial to define a common 
MFH reference building. For these reasons, for integration of passive and active (solar) façades in the residential sector, individual buildings (a virtual case study) will be taken into account for each study. It can have either an individual reference system (heat/cold emission and distribution as well as heating/cooling technology) or a standard reference system (e.g. electric heating, air-sourced heat pump, etc.).

The individual building with the reference system serves as a benchmark. The solar envelope solutions are compared against this benchmark in terms of energy performance.

Such an individual building model can consist of:

- A room (real or simplified but geometrical correct representation of a room);

- A group of rooms (one thermal zone, consisting of one room or several rooms with similar orientation and occupation profile);

- A flat or the entire building or a part of it (consisting of one or more thermal zones, which represent rooms or group of rooms).

In case of individual reference building, zoning has to be chosen carefully and has to be well described:

- For each zone, geometry can be real or simplified, occupation and internal gains can be flat or scheduled;

- Heating/cooling and ventilation can be central/decentral, which influences zoning;

- Control can be room- (i.e. zone-) wise or with respect to a central (averaged) measured quantity.

The second approach (benchmark) with an individual building with reference system is used for the residential buildings (MFHs) (results will be provided in Deliverable DC.2 parts B1, B2).

In order to report the performance of both, residential and non-residential buildings, the same KPIs, as defined in section 5 , should be used.

\subsection{Reference office description}

This paragraph provides a description of parameters and characteristics of the office building used as a reference. The aim is to use this as a common reference case in simulation studies, to enable yearly performance evaluation of different solar active façade technologies. The office zone is representative of a new office space, where building envelope characteristics vary according to the European climatic conditions.

Since some boundary conditions here reported might not be in accordance or compatible with a given solar active technology, these are modifiable according to the specific case. For example, if the solar active façade concept includes a strategy for dimming the lighting power according to the solar availability on the façade surface (e.g. shading device with indoor illuminance sensor), then recommended instantaneous lighting gains and the control strategy of external shadings can be neglected (although lighting schedules must be respected anyhow). The same approach applies for the definition of building envelope elements. When building-integrated technologies are fully or partly integrated in the structure of the façade, reference assemblies can be neglected.

\subsubsection{Geometry}

Due to the potentially high computational efforts, the energy analysis of high-rise office buildings by means of transient simulations needs adequate simplifications in the development of a numerical model. Since the goal is to carry out an analysis on the energy contribution of different solar active façade technologies in covering building loads and to evaluate indoor comfort conditions, the definition of a detailed architectural building geometry is of less importance. Thus, simplifications and assumptions on building geometry and user behaviour are necessary and a good trade-off between accuracy of the model and computational efforts has to be found.

The first step consists in simplifying a real building geometry by identifying elementary modules. A first statement assumes that the energy performance of high-rise buildings can be derived from the energy performance of a single reference storey. The selection of a reference floor has to rely on the specificity of the building's geometry (geometry aspect ratio and the total number of floors) and boundary conditions (orientation and shading from surroundings). In general, mid-floors are considered to be representative, whereas ground coupled zones or roof attached spaces are not taken into account [1]. A second simplification consists in assuming that the energy behaviour of the reference floor can be assimilated to that of a series of reference office cells oriented according to the building's exposures. The validity of this last statement really depends on the floor area and its aspect ratio. 
Based on experience of the participants, a reference office space is defined (see Figure 3-1). The office has a rectangular floor plan, it has a gross floor area and volume of $27 \mathrm{~m}^{2}$ and $81 \mathrm{~m}^{3}$, respectively and the dimensions are:

- $\quad$ Length: $6.0 \mathrm{~m}$;

- Width: $4.5 \mathrm{~m}$;

- Height: $3.0 \mathrm{~m}$.

The window height is $1.20 \mathrm{~m}$ from the floor as shown in Figure 3-1. The façade is assumed to be composed by three modules with length of $1.50 \mathrm{~m}$ where solar active technologies are installed. The gross window-to-wall ratio (including façade frame ${ }^{1}$ ) is assumed to be $60 \%$. Solar active technologies are installed on the external façade where ambient boundary conditions are applied. The remaining five surfaces have adiabatic boundary conditions (no heat flow between adjacent zones). The thermal capacity of the air node is multiplied by 10 (987 kJ/K for a 81 $\mathrm{m}^{3}$ air volume in place of $98.7 \mathrm{~kJ} / \mathrm{K}$ ) to account for the thermal mass of the furniture. The air density is $1.204 \mathrm{~kg} / \mathrm{m}^{3}$. In order to precondition the thermal mass of the air node and of the walls, a total of 13 months is simulated where the first month should be December of the previous year. Only the last 12 months should be considered in the results. It is also important to consider the first day of January as Monday in order to align the internal gains (see section 3.3.2).

Although building orientation can vary in practice, South is taken into account as main direction (in the Northern hemisphere). West and East directions can additionally be considered.

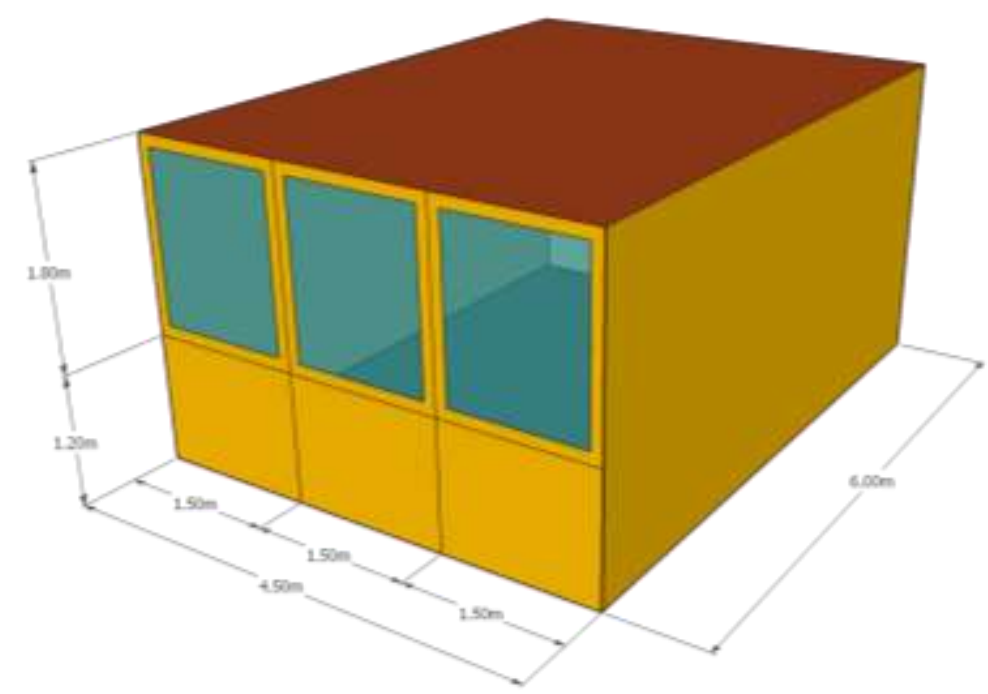

Figure 3-1: View of the reference office zone

\subsubsection{Internal gains}

\section{Occupancy}

The reference office zone is conceived for hosting 3 people ( $9 \mathrm{~m}^{2} /$ person). According to typical office activity level (1.2 met), human presence causes sensible gains ( $70 \mathrm{~W} /$ person) and latent gains $(0.08 \mathrm{~kg} / \mathrm{h} /$ person) [2]. Sensible gains are further divided into convective $(60 \%)$ and radiative $(40 \%)$ contributions. In order to evaluate indoor comfort conditions during the year, a clothing factor of 0.85 [3] and a metabolism index of 1.2 are considered [3].

The presence of occupants during the working days has been defined according to the hourly schedule shown in Figure 3-2, while during the weekend the occupancy is set to zero. The contemporaneity factor used to account for vacation and sickness periods is assumed to be constant and equal to 0.8 . The simulation week starts on Monday.

\footnotetext{
${ }^{1}$ The net transparent surface amounts to $2.022 \mathrm{~m}^{2}$ (net window-to-wall ratio 45\%), with a window frame of $11 \mathrm{~cm}$ thick.
} 


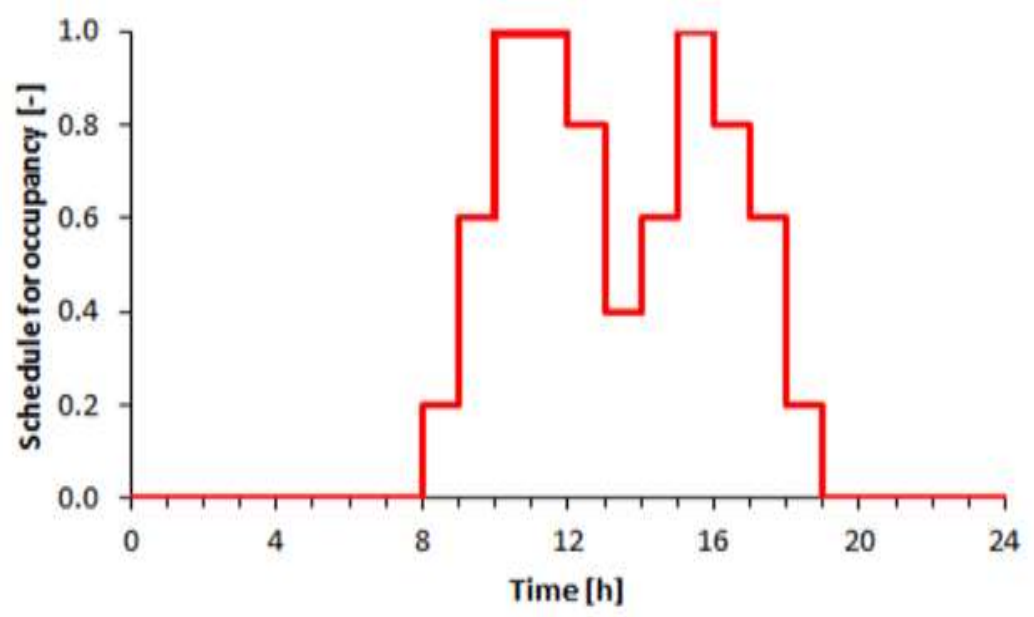

\begin{tabular}{ccc} 
From: & To: & Value \\
\hline $00: 00$ & $08: 00$ & 0.0 \\
$08: 00$ & $09: 00$ & 0.2 \\
$09: 00$ & $10: 00$ & 0.6 \\
$10: 00$ & $11: 00$ & 1.0 \\
$11: 00$ & $12: 00$ & 1.0 \\
$12: 00$ & $13: 00$ & 0.8 \\
$13: 00$ & $14: 00$ & 0.4 \\
$14: 00$ & $15: 00$ & 0.6 \\
$15: 00$ & $16: 00$ & $1: 0$ \\
$16: 00$ & $17: 00$ & 0.8 \\
$17: 00$ & $18: 00$ & 0.6 \\
$18: 00$ & $19: 00$ & 0.2 \\
$19: 00$ & $24: 00$ & 0.0
\end{tabular}

Figure 3-2: Occupancy schedule profile during working days (from Monday to Friday) [2]

\section{Appliances}

Internal gains due to appliances for typical office spaces is assumed to be $7.0 \mathrm{~W} / \mathrm{m}^{2}$ [2]. The convective fraction is fixed to $70 \%$, while the remaining part is radiative. The latent fraction is null. The appliances schedule profile is shown in Figure 3-3. During weekends and non-occupied hours, a standby consumption (10\%) is considered. As for the occupation internal gains, a contemporaneity index of 0.8 is assumed throughout the year [2].

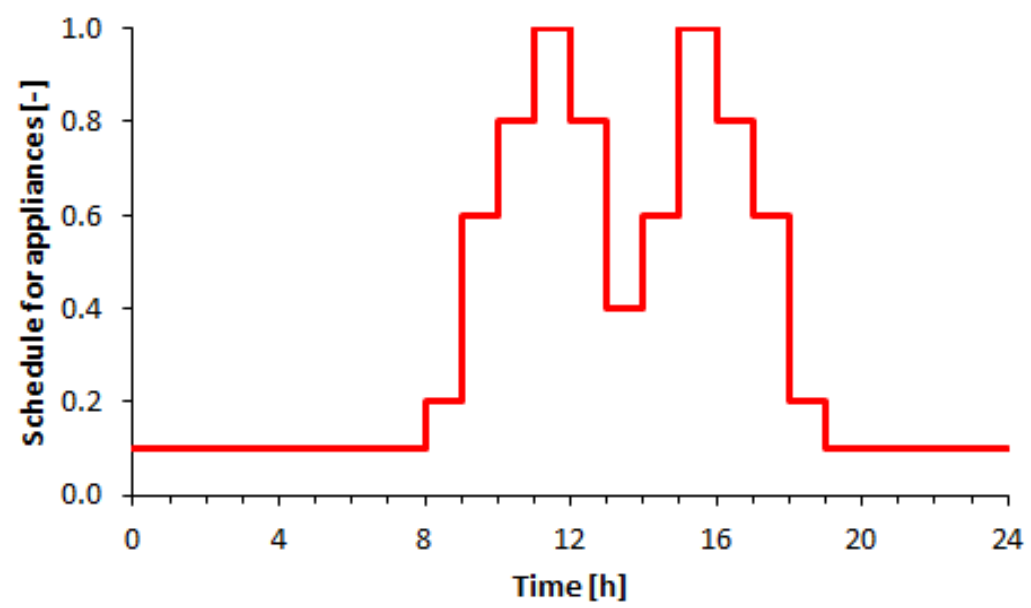

\begin{tabular}{ccc} 
From: & To: & Value \\
\hline $00: 00$ & $08: 00$ & 0.1 \\
$08: 00$ & $09: 00$ & 0.2 \\
$09: 00$ & $10: 00$ & 0.6 \\
$10: 00$ & $11: 00$ & 0.8 \\
$11: 00$ & $12: 00$ & 1.0 \\
$12: 00$ & $13: 00$ & 0.8 \\
$13: 00$ & $14: 00$ & 0.4 \\
$14: 00$ & $15: 00$ & 0.6 \\
$15: 00$ & $16: 00$ & 1.0 \\
$16: 00$ & $17: 00$ & 0.8 \\
$17: 00$ & $18: 00$ & 0.6 \\
$18: 00$ & $19: 00$ & 0.2 \\
$19: 00$ & $24: 00$ & 0.1
\end{tabular}

Figure 3-3: Appliances schedule profile during working days (from Monday to Friday) [2].

\section{Lighting}

The activation of lights during working days is based on the presence of occupants (see Figure 3-4). During weekends, lighting gains are not considered. Internal gains due to lighting are computed assuming that 500 lux on the working desk is available. This luminance level depends on several aspects, among which other façade optical characteristics, office geometry and weather conditions. Hence, a preliminary calculation is required in order to guarantee that prescribed values are reached. The artificial lighting system is responsible for an internal gain of $10.9 \mathrm{~W} / \mathrm{m}^{2}$, with a convective fraction of $2 / 3$ of the total gain. For the sake of simplicity, no dimming strategy is implemented in the simulation. 


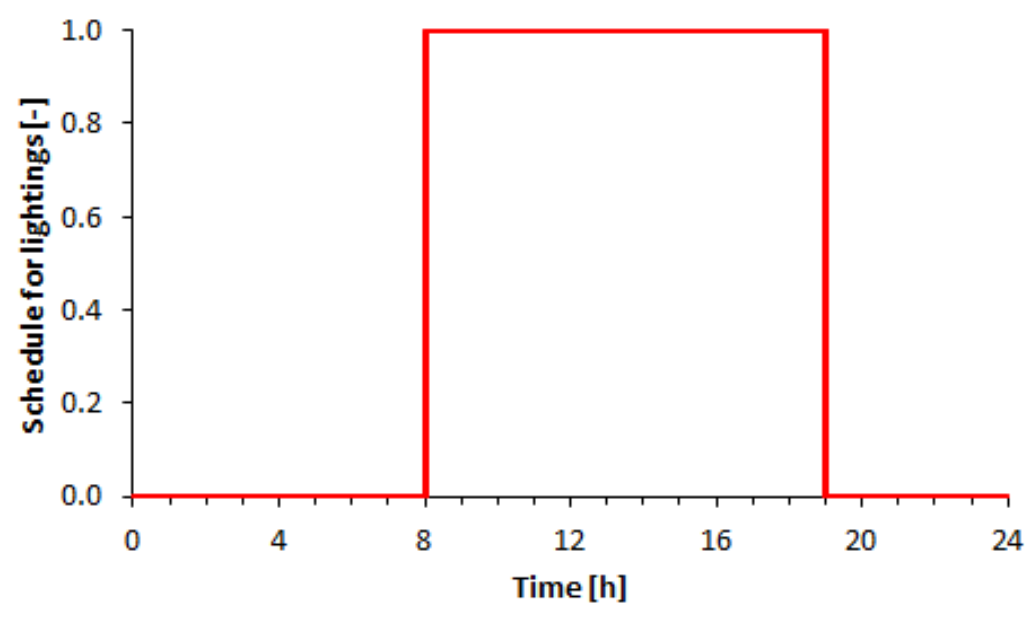

From: To: Value

00:00 08:00 0.0

08:00 19:00 1.0

$19: 00 \quad 24: 00 \quad 0.0$

Figure 3-4: Lighting schedule profile during working days (from Monday to Friday)

\subsubsection{Ventilation and infiltration}

A natural air change rate of $0.151 / \mathrm{h}$ due to infiltration through the façade is assumed. This value is considered constant throughout the year.

The fresh air is supplied, through a mechanical ventilation system, during occupancy hours at a constant rate (40 $\mathrm{m}^{3} / \mathrm{h} /$ person). A specific fan power of $0.55 \mathrm{~W} / \mathrm{m}^{3} / \mathrm{h}$ has to be adopted. The electric power of the fans is not recovered in the system. A heat recovery unit is further included with a sensible efficiency of $70 \%$ [2]. The heat recovery unit is by-passed when the temperature of the zone is higher than $23^{\circ} \mathrm{C}$ and the external air is lower than the indoor air temperature with a $0.5 \mathrm{~K}$ hysteresis (see Figure 3-5) with constant fan power. To prevent frost formation in the secondary side of the exhaust air in the heat recovery unit, a frost protection technique is included (see Figure 3-6). It consists of including an ideal electric resistance at the inlet section of the exhaust air that guarantees a minimum inlet temperature of $0^{\circ} \mathrm{C}$.

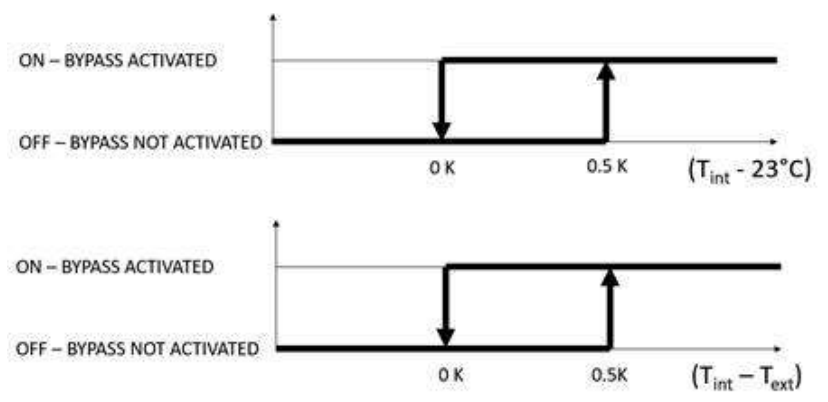

Figure 3-5: ventilation bypass control strategy

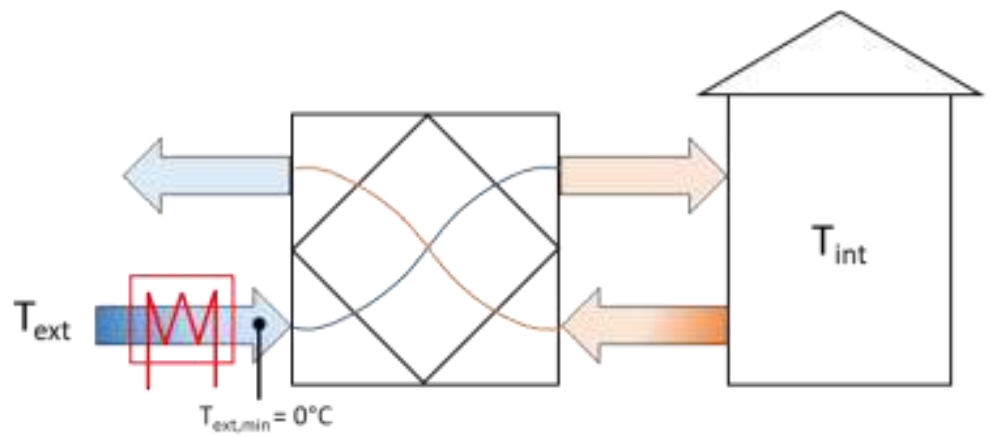

Figure 3-6: position of the frost protection 


\subsubsection{Shadings}

The solar shading consists of generic external movable shading blinds that are able to block $70 \%$ of the solar radiation impinging the whole window area. The shading device is activated when the beam solar radiation incident on the external façade (vertical plane) exceeds a threshold of $120 \mathrm{~W} / \mathrm{m}^{2}$. The shading system reduces the solar radiation impinging both frame and glass of the windows without influencing the thermal properties (it does not add any thermal resistance to the window).

No influence of the urban or environmental context in terms of unwanted shading on the active solar façade modules is considered.

\subsubsection{Building assemblies}

\section{Opaque structures}

The thermal and optical characteristics of opaque assemblies and building materials are listed from Table 3-1 to

Table 3-5.

Table 3-1: Construction of internal walls

\begin{tabular}{lcccc} 
Material & $\begin{array}{c}\mathbf{s} \\
{[\mathbf{m}]}\end{array}$ & $\begin{array}{c}\boldsymbol{\lambda} \\
{[\mathbf{W} / \mathbf{m K}]}\end{array}$ & $\begin{array}{c}\mathbf{\rho} \\
{\left[\mathbf{k g} / \mathbf{m}^{3}\right]}\end{array}$ & $\begin{array}{c}\mathbf{c}_{\mathbf{p}} \\
{[\mathbf{k J} /(\mathbf{k g K})]}\end{array}$ \\
\hline Plasterboard & 0.024 & 0.160 & 950 & 0.84 \\
Mineral wool & 0.080 & 0.038 & 80 & 0.84 \\
Plasterboard & 0.024 & 0.160 & 950 & 0.84 \\
\hline
\end{tabular}

For ceiling and floor, the same structure is considered, but the layers order from inside to outside is:

- $\quad$ Carpet, screed and concrete for the floor;

- Concrete, screed and carpet for the ceiling.

Table 3-2: Construction of floor/ceiling

\begin{tabular}{lcccc} 
Material & $\begin{array}{c}\mathbf{s} \\
{[\mathbf{m}]}\end{array}$ & $\begin{array}{c}\boldsymbol{\lambda} \\
{[\mathbf{W} / \mathbf{m K}]}\end{array}$ & $\begin{array}{c}\boldsymbol{\rho} \\
{\left[\mathbf{k g} / \mathbf{m}^{3}\right]}\end{array}$ & $\begin{array}{c}\mathbf{c}_{\mathbf{p}} \\
{[\mathbf{k J} /(\mathbf{k g K})]}\end{array}$ \\
\hline Carpet & 0.005 & 0.060 & 200 & 1.30 \\
Screed & 0.120 & 0.080 & 350 & 0.40 \\
Concrete & 0.350 & 2.100 & 2500 & 0.84 \\
\hline
\end{tabular}

The insulation thickness of the external wall façade has to comply with requirements prescribed in national building codes. Since these might be different from country to country and from project to project, a pragmatic approach is recommended. From FP7 EU iNSPiRe project [4], three insulation levels of external wall are identified (Table 3-3 and Table 3-4).

Table 3-3: Construction of external wall

\begin{tabular}{lcccc} 
Material & $\begin{array}{c}\mathbf{s} \\
{[\mathbf{m}]}\end{array}$ & $\begin{array}{c}\boldsymbol{\lambda} \\
{[\mathbf{W} / \mathbf{m K}]}\end{array}$ & $\begin{array}{c}\mathbf{\rho} \\
{\left[\mathbf{k g} / \mathbf{m}^{3}\right]}\end{array}$ & $\begin{array}{c}\mathbf{c}_{\mathbf{p}} \\
{[\mathbf{k J} /(\mathbf{k g K})]}\end{array}$ \\
\hline Aluminium & 0.003 & 200 & 2700 & 0.86 \\
Mineral wool & variable & 0.038 & 80 & 0.84 \\
Aluminium & 0.003 & 200 & 2700 & 0.86 \\
\hline
\end{tabular}

Table 3-4: Thermal transmittance and insulation thickness of the external façade opaque element according the climatic regions

\begin{tabular}{lcc} 
Climatic zone & $\begin{array}{c}\text { U-wall } \\
{\left[\mathbf{W} /\left(\mathbf{m}^{2} \mathbf{K}\right)\right]}\end{array}$ & $\begin{array}{c}\text { Insulation } \\
\text { thickness }[\mathbf{c m}]\end{array}$ \\
\hline Stockholm & 0.3 & 12 \\
Stuttgart & 0.4 & 9 \\
Rome & 0.8 & 4 \\
\hline
\end{tabular}


Table 3-5: Characteristics of indoor surfaces (valid for the overall solar spectrum)

\begin{tabular}{l|cc} 
Material & Absorptance [-] & Emissivity [-] \\
\hline Plasterboard & 0.6 & 0.900 \\
Carpet & 0.6 & 0.900 \\
Concrete & 0.6 & 0.900 \\
Window frame & 0.3 & 0.900 \\
\hline
\end{tabular}

\section{Transparent structures}

The thermal and optical characteristics of windows are specific to each installation and largely depend on climatic conditions and project objectives. In order to provide a reference, three glazing assemblies are defined in Table 3-6. These assemblies are derived from the window library of TRNSYS [5] and correspond to WIN-ID 3304, 2001 and 2206, respectively. A detailed description of the windows assemblies is reported in appendix A. 2. The frame has a thermal transmittance (U-frame) equal to $1.18 \mathrm{~W} /\left(\mathrm{m}^{2} \mathrm{~K}\right)$ and covers the $25 \%$ of the total window area.

Table 3-6: Thermal and optical characteristics of transparent structures

\begin{tabular}{l|ccccccc} 
Location & Description & Assembly & $\begin{array}{c}\mathbf{U}-\text { glass } \\
{\left[\mathbf{W} /\left(\mathbf{m}^{2} \mathbf{K}\right)\right]}\end{array}$ & $\begin{array}{c}\text { g-value } \\
{[-]}\end{array}$ & $\begin{array}{c}\text { T-sol } \\
{[-]}\end{array}$ & $\begin{array}{c}\text { Rf-sol } \\
{[-]}\end{array}$ & $\begin{array}{c}\text { T-vis } \\
{[-]}\end{array}$ \\
\hline Stockholm & $\begin{array}{c}\text { Double glazing filled } \\
\text { w. Krypton }\end{array}$ & $4 / 16 / 4$ & 0.81 & 0.632 & 0.462 & 0.237 & 0.749 \\
Stuttgart & $\begin{array}{c}\text { Double glazing filled } \\
\text { w. Argon }\end{array}$ & $4 / 16 / 4$ & 1.40 & 0.589 & 0.426 & 0.266 & 0.706 \\
Rome & $\begin{array}{c}\text { Double glazing filled } \\
\text { w. Argon }\end{array}$ & $6 / 16 / 6$ & 1.29 & 0.333 & 0.260 & 0.218 & 0.659 \\
\hline
\end{tabular}

\subsubsection{Energy system}

\section{Energy generation and distribution system}

The space heating and cooling energy generation and distribution system is assumed to be ideal. More specifically, it is assumed that such system is able to provide the thermal zone with exactly the required power to bring the convective air temperature to the set point temperature during each time-step. The maximum space heating and cooling power that can be delivered in one time-step is not limited. It is assumed that space heating and cooling power can be delivered during the whole year. Likewise, humidification and dehumidification are performed by an ideal system.

\section{Set points}

The convective indoor air temperature set point is fixed at $21^{\circ} \mathrm{C}$ for space heating and $25^{\circ} \mathrm{C}$ for space cooling. If the modelling of an ideal heating and cooling is not possible a dead-band of $\pm 0.5 \mathrm{~K}$ has to be implemented. Concerning the humidity level in the occupied space, the absolute humidity has to be kept within typical comfort ranges throughout the year that is between $4.5 \mathrm{gv} / \mathrm{kg}_{\mathrm{a}}$ and $13.5 \mathrm{gv} / \mathrm{kg}_{\mathrm{a}}$.

\subsubsection{Hot water demand}

The reference hot water demand for offices amounts to $3.0 \mathrm{l} /$ person/day (weekdays only) produced at $60^{\circ} \mathrm{C}$ [2]. The temperature of cold tap water is assumed to be constant at $10^{\circ} \mathrm{C}$. The default DHW system is an electric boiler with $5 \mathrm{I}$ water content and $\mathrm{ErP}$ class $\mathrm{A}(\mathrm{UA}=0.37 \mathrm{~W} / \mathrm{K})$.

\subsubsection{Daylight analysis}

Horizontal illuminance sensors (lux) are installed at work plane height of $0.75 \mathrm{~m}$ above the floor. The two sensor points are defined in the middle line of the office room: one at a façade-near position with $1.5 \mathrm{~m}$ behind the façade and another at a façade-far position with $4.5 \mathrm{~m}$ behind the façade. For assessing spatial daylight autonomy (sDA) a grid of, equidistantly spaced, sensor points is defined. The sensors should be placed equidistantly and spaced at least 0.5 meters apart.

Interior surfaces are assumed to be ideally diffusing and their reflectance values for the interior surfaces are presented in Table 3-7. 
Table 3-7 Visible diffuse reflectance values for different elements

\begin{tabular}{c|cccc} 
& Ceiling & Walls & Floor & Ground and Outdoor Obstructions \\
\hline Visible reflectance $\rho$ & 0.8 & 0.5 & 0.3 & 0.2 \\
\hline
\end{tabular}

\section{Climates}

The seasonal performances of solar envelopes are evaluated with respect to reference climate conditions. In particular, three reference locations are selected, representing typical cold, medium and warm European climates (see Figure 4-1 and Table 4-1, see EU-project iNSPiRe [4]).

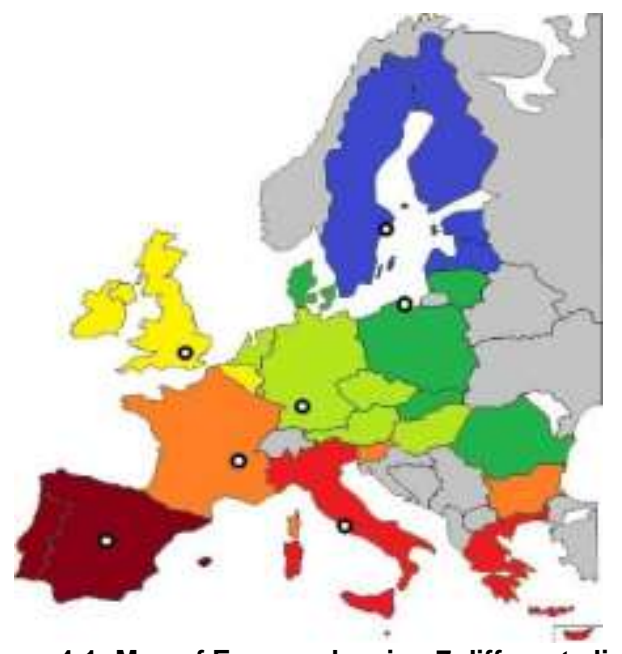

\begin{tabular}{c|cc} 
& HDD & HDDS \\
\hline Stockholm & 3997.8 & 3887.7 \\
Gdansk & 3885.4 & 3823.9 \\
Stuttgart & 3218.9 & 3241.8 \\
London & 2676.5 & 2701.4 \\
Lyon & 2795.7 & 2287.4 \\
Madrid & 2061.9 & 1949.6 \\
Rome & 1354.2 & 1380.8 \\
\hline
\end{tabular}

Heating degree days (HDD) and Heating degree days calculated with solar air temperature (HDDs), acc. to Eq 4-1 and 4.3.

Figure 4-1: Map of Europe showing 7 different climate regions represented by the cities of Stockholm, Gdansk London, Stuttgart, Lyon, Madrid and Rome, [4] with heating degree days.

Table 4-1: List of reference locations (GPS-coordinates and elevation).

\begin{tabular}{l|lccc}
\multicolumn{1}{c}{ Location } & Climatic zone & \multicolumn{2}{c}{ Latitude } & \multicolumn{2}{c}{ Longitude } & \multicolumn{2}{c}{$\begin{array}{c}\text { Elevation } \\
{\left[{ }^{\circ}\right]}\end{array}$} & $\begin{array}{c}{\left[^{\circ}\right]} \\
{[m]}\end{array}$ \\
\hline Stockholm - Bromma (Sweden) & Nordic & N 5920 & E 18 03 & 15 \\
Stuttgart - Echterdingen (Germany) & Continental & N 48 41 & E 09 11 & 247 \\
Rome - Fiumicino (Italy) & Mediterranean & N 41 46 & E 12 29 & 37 \\
\hline
\end{tabular}

Remark: In Europe Strasbourg is often used as reference climate, Heating Degree Days are very close to those of Stuttgart (see Table 4-2).

Table 4-2: Strasbourg Climate and location

\begin{tabular}{c|lccccc} 
Location & Climatic zone & $\begin{array}{c}\text { Latitude } \\
{\left[{ }^{\circ}\right]}\end{array}$ & $\begin{array}{c}\text { Longitude } \\
{\left[{ }^{\circ}\right]}\end{array}$ & $\begin{array}{c}\text { Elevation } \\
{[\mathrm{m}]}\end{array}$ & $\begin{array}{c}\text { HDD } \\
{[\mathrm{Kd}]}\end{array}$ & $\begin{array}{c}\text { HDDs } \\
{[\mathrm{kd}]}\end{array}$ \\
\hline Strasbourg & Continental & $\mathrm{N} 4835$ & $\mathrm{E} 0745$ & 132 & 3261.0 & 3283.9 \\
\hline
\end{tabular}

The climate datasets are generated using the database Meteonorm v7 [6]. They contain hourly values of ambient air temperature, humidity, pressure, solar radiations, cloudiness and other meteorological parameters for a 1-year period, derived from hourly measures recorded over the period 2000-2009. The so-derived yearly datasets are representative of a typical average climatic year. In Table 4-3, average climatic parameters are calculated for the three locations and in particular:

- $\quad I_{g, h}\left[\mathrm{kWh} /\left(\mathrm{m}^{2} \mathrm{y}\right)\right]$ and $I_{b, h}\left[\mathrm{kWh} /\left(\mathrm{m}^{2} \mathrm{y}\right)\right]$ are the solar global and beam radiation on the horizontal plane;

- $\vartheta_{a m b, \min }\left[{ }^{\circ} \mathrm{C}\right]$ and $\vartheta_{a m b, \max }\left[{ }^{\circ} \mathrm{C}\right]$ are the minimum and maximum dry-bulb ambient temperature during the year; 
- $\quad$ winter and summer seasons are defined as the period in which average 24 -hours ambient temperature is below $12^{\circ} \mathrm{C}$ and above $18^{\circ} \mathrm{C}$, respectively;

- Heating Degree Days (HDD) are defined as the sum of the absolute values of differences between the daily average indoor temperature $\left(\vartheta_{i}=20^{\circ} \mathrm{C}\right)$ and the daily average ambient temperature $\left(\vartheta_{e}\right)$, in case the daily average ambient temperature is lower than a base temperature $\left(\vartheta_{\text {base_winter }}=12^{\circ} \mathrm{C}\right.$ in this case). Similarly, Cooling Degree Days (CDD) are defined for the summer period as the sum of the absolute values of differences between the daily average ambient temperature and a base temperature $\left(\vartheta_{\text {base_summer }}=18^{\circ} \mathrm{C}\right.$ in this case), in case the daily average ambient temperature is higher than the base temperature .

$$
\begin{gathered}
H D D=\sum\left|\vartheta_{i}-\vartheta_{e}\right| \cdot\left(\vartheta_{e}<\vartheta_{\text {base_winter }}\right) \\
C D D=\sum\left|\vartheta_{e}-\vartheta_{\text {base_summer }}\right| \cdot\left(\vartheta_{e}>\vartheta_{\text {base_summer }}\right)
\end{gathered}
$$

- HDDs is the heating degree days calculated with the solar air temperature $\left(\vartheta_{s o l, a}\right)$, calculated on monthly basis according to:

$$
\begin{gathered}
H D D s=\sum\left(\vartheta_{i}-\vartheta_{s o l, a}\right) \cdot\left(\vartheta_{\text {sol }, a}<\vartheta_{\text {base_winter }}\right) \\
\vartheta_{\text {sol,a }}=\vartheta_{a}+\frac{\alpha_{s}}{h_{e}} \cdot I_{s}-X
\end{gathered}
$$

Where:

- $\vartheta_{a}$ is the ambient temperature $\left[{ }^{\circ} \mathrm{C}\right]$;

- $I_{s}$ is the average global solar radiation in $\left[\mathrm{W} / \mathrm{m}^{2}\right]$;

- $\alpha_{\mathrm{s}}=0.65, \mathrm{~h}_{\mathrm{e}}=25 \mathrm{~W} /\left(\mathrm{m}^{2} \mathrm{~K}\right)$;

- $\quad X=3.9 \mathrm{~K}$.

Table 4-3: Yearly climatic parameters

\begin{tabular}{l|cccccccc} 
Location & $\begin{array}{c}\mathbf{I}_{\mathbf{g}, \mathbf{h}} \\
{\left[\mathbf{k W h} /\left(\mathbf{m}^{2} \mathbf{y}\right)\right]}\end{array}$ & $\begin{array}{c}\mathbf{I}_{\mathbf{b}, \mathbf{h}} \\
{\left[\mathbf{k W h} /\left(\mathbf{m}^{2} \mathbf{y}\right)\right]}\end{array}$ & $\begin{array}{c}\boldsymbol{\vartheta}_{\mathbf{a m b}, \min } \\
{\left[{ }^{\circ} \mathbf{C}\right]}\end{array}$ & $\begin{array}{c}\boldsymbol{\vartheta}_{\mathbf{a m b}, \max } \\
{\left[{ }^{\circ} \mathbf{C}\right]}\end{array}$ & $\begin{array}{c}\text { Winter period } \\
{[\mathbf{h}]}\end{array}$ & $\begin{array}{c}\text { HDD } \\
{[\mathbf{K d}]}\end{array}$ & $\begin{array}{c}\text { Summer period } \\
{[\mathbf{h}]}\end{array}$ & $\begin{array}{c}\text { CDD } \\
{[\mathrm{Kd}]}\end{array}$ \\
\hline Stockholm & 953 & 478 & -16.3 & 29.6 & 5771 & 3998 & 1004 & 92 \\
Stuttgart & 1104 & 524 & -12.4 & 32.3 & 5041 & 3220 & 1418 & 163 \\
Rome & 1637 & 1013 & -1.4 & 33.1 & 2802 & 1355 & 3535 & 639 \\
\hline
\end{tabular}

Since a building integrated solar technology could be developed for specific climatic conditions, it makes sense to evaluate its performance under one or more of the three locations here proposed. In case there are additional locations to evaluate, it is requested to calculate the yearly and monthly average climatic parameters of Table 4-3, Figure 4-2 and Figure 4-3 and to compare them against those of the reference locations. 


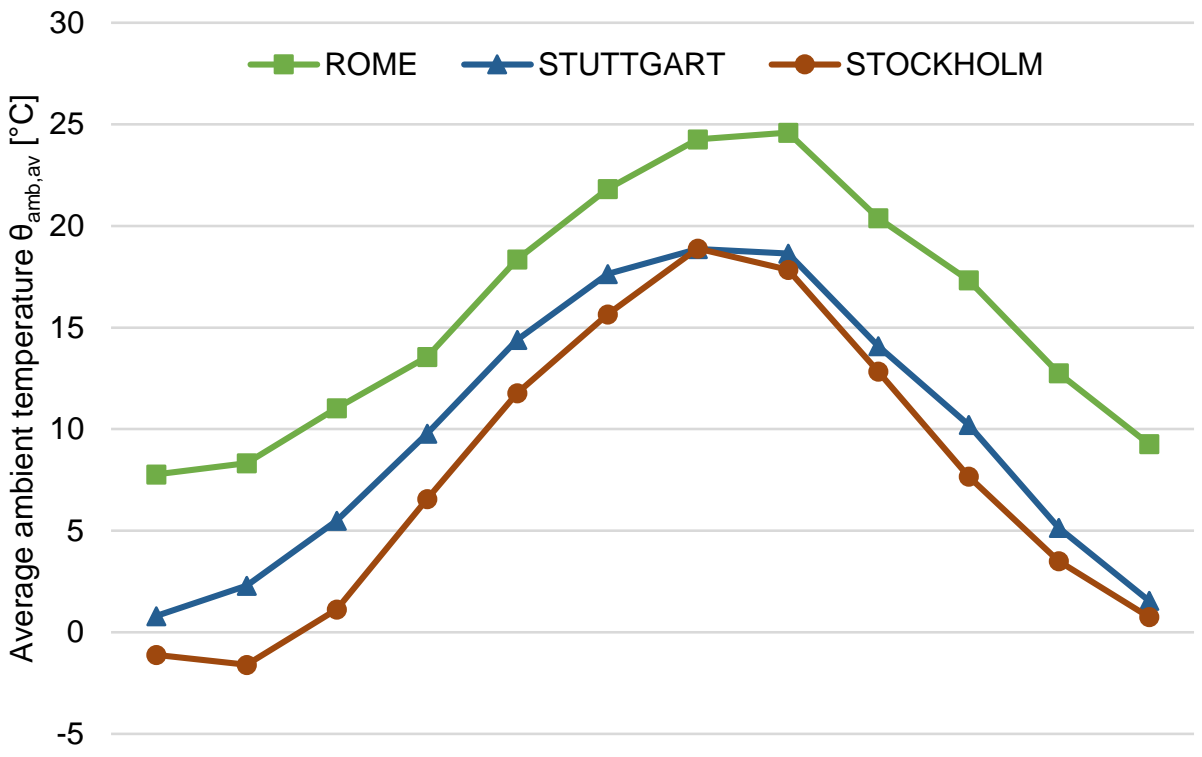

Figure 4-2: Monthly average dry-bulb ambient temperature for the locations of Rome, Stuttgart and Stockholm

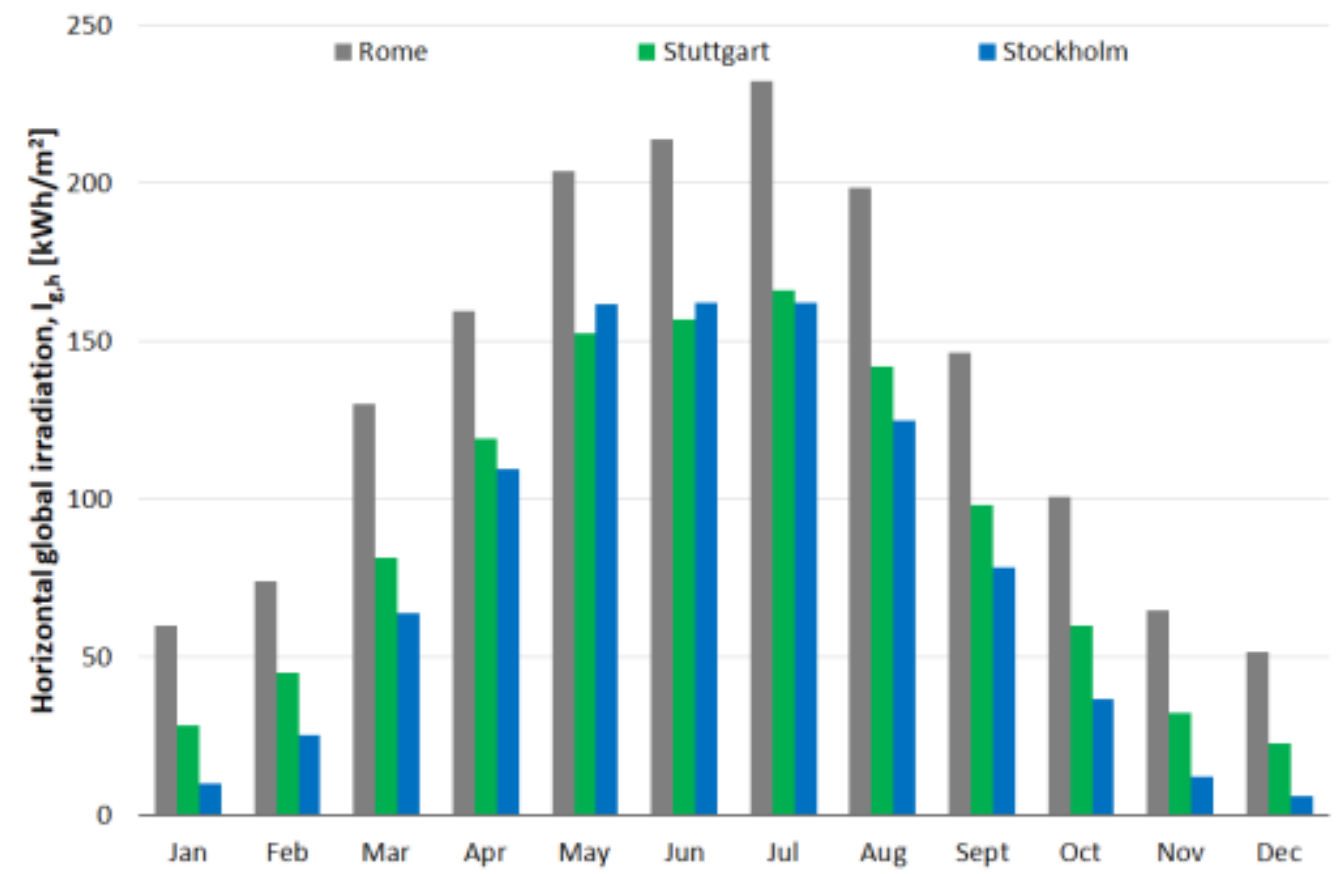

Figure 4-3: Monthly horizontal global irradiation for the locations of Rome, Stuttgart and Stockholm

In Table 4-4 the monthly average ambient temperature and the monthly horizontal global irradiation are reported for the climates of Rome, Stuttgart and Stockholm. 
Table 4-4 (A) Average ambient temperature, (B) Horizontal global irradiation for the climates of Stockholm, Stuttgart and Rome

\begin{tabular}{l|ccc}
\multirow{2}{*}{ Month } & \multicolumn{3}{|c}{ Average ambient temperature, $\boldsymbol{\theta}_{\text {amb,av }}$} \\
& \multicolumn{3}{|c}{${ }^{\circ} \mathbf{C}$ ] } \\
\cline { 2 - 4 } & Stockholm & Stuttgart & Rome \\
\hline January & -1.1 & 0.8 & 7.8 \\
February & -1.6 & 2.3 & 8.3 \\
March & 1.1 & 5.5 & 11.0 \\
April & 6.6 & 9.8 & 13.5 \\
May & 11.8 & 14.4 & 18.4 \\
June & 15.6 & 17.6 & 21.8 \\
July & 18.9 & 18.9 & 24.3 \\
August & 17.8 & 18.7 & 24.6 \\
September & 12.8 & 14.1 & 20.4 \\
October & 7.7 & 10.2 & 17.3 \\
November & 3.5 & 5.1 & 12.7 \\
December & 0.8 & 1.6 & 9.3 \\
\hline
\end{tabular}

\begin{tabular}{l|ccc}
\multirow{2}{*}{ Month } & \multicolumn{3}{|c}{ Horizontal global irradiation, $\mathbf{I}_{\mathbf{g}, \mathbf{h}}$} \\
& \multicolumn{3}{|c}{$\left[\mathbf{k W h} / \mathbf{m}^{\mathbf{2}}\right]$} \\
\cline { 2 - 4 } & Stockholm & Stuttgart & Rome \\
\hline January & 10.0 & 28.7 & 60.0 \\
February & 25.3 & 45.0 & 74.2 \\
March & 64.0 & 81.5 & 130.2 \\
April & 109.7 & 119.2 & 159.6 \\
May & 161.9 & 152.5 & 203.7 \\
June & 162.1 & 156.8 & 214.0 \\
July & 162.4 & 166.0 & 232.4 \\
August & 124.8 & 141.9 & 198.8 \\
September & 78.5 & 97.9 & 146.4 \\
October & 36.6 & 59.8 & 100.7 \\
November & 12.1 & 32.4 & 65.1 \\
December & 6.2 & 22.8 & 51.6 \\
\hline Total & $\mathbf{9 5 3 . 6}$ & $\mathbf{1 1 0 4 . 5}$ & $\mathbf{1 6 3 6 . 7}$
\end{tabular}

(A)

(B) 


\section{Key Performance Indicators (KPIs)}

In this section the definitions of the Key Performance Indicators (KPIs) useful for the evaluation of the simulation results are given:

- Heating/cooling demands

- Heating/cooling loads

- DHW demand

- $\quad$ Electricity needs (auxiliary energies, lighting and appliances)

Based on the useful energy (UE), the final energy demand (FE) can be determined depending on the performance of the used HVAC system and on the amount and type of RE use. Moreover, the Primary Energy (PE) and $\mathrm{CO}_{2}-$ emissions have to be determined.

Additionally, the following points need to be considered:

- Thermal comfort

- Indoor Air quality (IAQ) and

- Visual Comfort

\subsection{HVAC system}

In IEA SHC Task 56, the impact of building integrated solar technologies are measured in terms of PE savings and savings in $\mathrm{CO}_{2}$ emissions.

Primary Energy (PE) converts Final Energy (FE) derived from an energy carrier (i.e. electricity, gas, oil, wood) into an equivalent fossil energy. In order to perform this calculation for the goals of IEA SHC Task 56, primary energy conversion factors $f_{P E}$ in $\mathrm{kWh} / \mathrm{kWh}$ FE are used.

$$
P E=\sum_{i} F E_{i} \cdot f_{P E, i}
$$

$\mathbf{C O}_{2}$ emissions is the weighted emission of different greenhouse gases when providing final energy, including emissions generated during the construction of the electric grid and power plants. It is calculated by multiplying a factor for specific $\mathrm{CO}_{2}$ - emissions of an energy carrier in $\mathrm{g} / \mathrm{kWh}$ by the final energy required to cover heating, cooling and domestic hot water as well as auxiliary energies, lighting and electricity consumption of equipment (appliances).

In Table 5-1, European average values for primary energy conversion factors $f_{P E}$ and $\mathrm{CO}_{2}$ conversion factors $f_{C O 2}$ for different energy carriers are shown.

Table 5-1: EU average values for $f_{\mathrm{PE}}$ for different energy carriers (total and non-RE primary energy conversion factor)

[7]

\begin{tabular}{l|ccc} 
Energy carrier & $\left.\begin{array}{c}\mathbf{f}_{\mathrm{PE}, \mathrm{TOT}} \\
{[\mathbf{k W h}}\end{array} \mathbf{h}_{\mathrm{PE}} / \mathbf{k W h} \mathbf{h}_{\mathrm{FE}}\right]$ & $\begin{array}{c}\mathbf{f}_{\mathrm{PE}, \mathrm{n} \cdot \mathrm{RE}} \\
{\left[\mathbf{k W h} \mathbf{h}_{\mathrm{PE}} / \mathbf{k W h} \mathbf{h}_{\mathrm{FE}}\right]}\end{array}$ & $\begin{array}{c}\mathbf{f}_{\mathrm{CO} 2} \\
{\left[\mathbf{g C O}_{2} / \mathbf{k W h} \mathbf{h}_{\mathrm{FE}}\right]}\end{array}$ \\
\hline Electricity & 2.5 & 2.3 & 420 \\
Gas & 1.1 & 1.1 & 220 \\
Oil & 1.1 & 1.1 & 290 \\
\hline
\end{tabular}

\section{Monthly Primary Energy Conversion Factors for Electricity}

National (or average EU) non-RE conversion factors for $\mathrm{PE} / \mathrm{CO}_{2}$ are not purely based on facts, but are partly politically motivated. They differ significantly between the EU member states and are subject to change, e.g. Germany non-renewable PE (EnEV 2014 Annex 1 section 2.1.1 [8]) 1.8 since 2016 (2.4 before), Austria fPEnon-RE 1.02 since 2019 , f PEnon-RE 1.32 since $2015,2.15$ before [9]. Seasonal variations are not considered at all.

Due to the volatile share of renewable energy in the grid (see e.g. the energy balance for Germany in 2015 (e.g. data from ENTSO-E [10]), a net energy balance to evaluate different efficiency and energy concepts can be misleading. Instead, a monthly evaluation based on monthly primary energy factors is proposed, which can be used to calculate a more representative environmental impact [11]. 
For the electricity mix, the share of renewables within the time frame of consideration (e.g. 20 years) should be included and not as usually done in the current or past status of the energy system. A significantly increased share of renewable electricity can be expected in the near future in particular in summer (PV), while in winter only a moderate increase is likely (further extension of wind power) unless seasonal storage capacities are strongly build up.

If a large number of buildings use heat pumps for space heating and DHW preparation and produce electricity (with $\mathrm{PV}$ ), both, the purchased electric energy and the share of renewables in the electricity mix and thus the $\mathrm{CO}_{2}$ conversion factor of the electricity are dependent. Electricity that is used on site is not available in the grid and an increased share of fossil fuels in the energy mix has to be considered. However, PV electricity sold to the grid will replace fossil fuels more likely in winter, spring and autumn than in summer. The primary energy conversion factor depends on both, the building load duration curve and the time dependent electricity mix. Examples of primary energy conversion factors for different shares of RE in the electricity mix are shown in the following Table 5-2. A detailed description of the approach can be found in the appendix A. 1.

Table 5-2: Examples for monthly non-RE primary energy conversion factor for electricity

\begin{tabular}{c|ccccccccccccc}
\multicolumn{1}{l}{} & Jan & Feb & Mar & Apr & May & Jun & Jul & Aug & Sep & Oct & Nov & Dec & Av. \\
\hline REF & 3.28 & 3.04 & 2.61 & 2.09 & 1.63 & 1.35 & 1.32 & 1.56 & 1.99 & 2.51 & 2.97 & 3.25 & $\mathbf{2 . 3}$ \\
A:10-10-10 & 2.01 & 1.96 & 1.89 & 1.60 & 1.33 & 1.20 & 1.18 & 1.28 & 1.53 & 1.78 & 1.92 & 2.01 & $\mathbf{1 . 6}$ \\
B:10-30-30 & 1.53 & 1.42 & 1.23 & 0.50 & 0.08 & 0.08 & 0.08 & 0.08 & 0.33 & 0.98 & 1.33 & 1.54 & $\mathbf{0 . 8}$ \\
\hline
\end{tabular}

The primary energy savings and the savings in $\mathrm{CO}_{2}$-emissions are calculated as the difference of the primary energy demand, or $\mathrm{CO}_{2}$-emissions, respectively, between the actual case and the reference case

$$
\begin{gathered}
\triangle P E=P E-P E_{\text {ref }} \\
\triangle C O 2=C O 2-C O 2_{\text {ref }}
\end{gathered}
$$

Where "ref" is the reference cell in case of office and is the individual reference building in case of residential.

The basis for the calculation of the primary energy (PE) and $\mathrm{CO}_{2}$ emissions are:

- The Useful Energy (UE). It is the thermal energy for space heating (i.e. heating demand HD) space cooling (i.e. cooling demand CD) and hot water (domestic hot water demand DHW) effectively made available to the user delivered by the HVAC system over the course of one year.

- $\quad$ The Final Energy (FE). According to Eurostat, it is the energy consumed by end users. It reaches the final consumer's door and excludes the share which is used by the energy sector itself for deliveries, transformation. FE equals to electricity for electrically driven systems, while for gas or biomass driven ones, it is calculated as the Higher Heating Value (HHV) of the used fuel multiplied by its mass consumption. Furthermore, auxiliary energies (e.g. fans) electricity for lighting and appliances must be considered.

All useful and final energy demand in particular heating and cooling demands should be given as monthly values in $\mathrm{kWh} /\left(\mathrm{m}^{2}\right)$ together with the indoor air temperature. The heating and cooling loads should be indicated by a sorted load duration curve based on daily average in $\mathrm{W} / \mathrm{m}^{2}$.

Beyond Primary Energy (PE) and $\mathrm{CO}_{2}$ savings, it might be relevant to calculate additional KPIs such as:

- Seasonal Performance Factor (SPF). For an electrically driven system, it expresses the performance of a system over a year or a season (i.e. heating or cooling). It is the ratio of the overall useful energy $Q_{j}$ output (space heating, cooling or hot water demands) to the overall driving final energy input $F E_{j}$ (electricity) for an adopted system boundary.

$$
S P F_{j}=\frac{Q_{j}}{F E_{j}}
$$


- $\quad$ Primary Energy Ratio (PER). The same calculation of SPF is carried out in terms of primary energy instead of final energy. For an electrically driven system, it expresses the performance of a system over a year or a season (i.e. heating or cooling). It is the ratio of the overall useful energy output (space heating, cooling or hot water loads) to the overall primary energy input for an adopted system boundary.

$$
P E R_{j}=\frac{Q_{j}}{P E_{j}}
$$

- Solar Fraction (SF), SF is defined as the percentage of load covered through solar-thermal energy.

$$
S F_{j}=\frac{Q_{S F, j}}{Q_{j}}
$$

\subsection{Thermal comfort}

HVAC system must guarantee comfort requirements and create a thermally comfortable environment during occupancy. There are several metrics commonly adopted to quantify the achievement of satisfying comfort conditions. These metrics are extensively described in ISO 7730 [3]. In the following text a description of the most useful KPIs for thermal comfort is presented.

- $\quad$ Predicted Mean Vote (PMV) and Predicted Percent of Dissatisfied people (PPD). These two indicators were derived by P.O. Fanger (ISO 7730 [3]) and combine the effect of metabolism, clothing factor, air velocity, air temperature, mean radiant temperature and humidity. Some of these factors are calculated through a numerical simulation of the office zone (air velocity, mean radiant temperature and humidity), while others like metabolism and clothing factor are a function of the occupancy typology. For the sake of this task purposes, it is assumed to consider for typical office buildings a clothing factor of 1.0 clo and metabolosim of 1.2 met. Then the desired thermal environment for a space may be selected from among the three categories $\mathrm{A}, \mathrm{B}$ and $\mathrm{C}$ according to Table 5-3.

Table 5-3: Categories of thermal environment.

\begin{tabular}{c|cc} 
Category & PPD [\%] & PMV \\
\hline A & $<6$ & $-0.2<\mathrm{PMV}<+0.2$ \\
$\mathrm{~B}$ & $<10$ & $-0.5<\mathrm{PMV}<+0.5$ \\
$\mathrm{C}$ & $<15$ & $-0.7<\mathrm{PMV}<+0.7$ \\
\hline
\end{tabular}

- Operative temperature $\left(\vartheta_{o p}\right)$. Indoor comfort conditions can be evaluated by calculating the occurrence of an operative temperature class during occupancy period. Five main classes are defined as follows:

1. discomfort conditions, too hot $\left(\vartheta_{o p} \geq 26^{\circ} \mathrm{C}\right)$;

2. discomfort conditions, moderate hot $\left(25^{\circ} \mathrm{C} \leq \vartheta_{o p}<26^{\circ} \mathrm{C}\right)$

3. comfort conditions $\left(21^{\circ} \mathrm{C} \leq \vartheta_{o p}<25^{\circ} \mathrm{C}\right)$;

4. discomfort conditions, moderate cold $\left(20^{\circ} \mathrm{C} \leq \vartheta_{o p}<21^{\circ} \mathrm{C}\right)$;

5. discomfort conditions, too cold $\left(\vartheta_{o p}<20^{\circ} \mathrm{C}\right)$.

$$
\vartheta_{o p}=a \cdot \vartheta_{c o n v}+(1-a) \cdot \vartheta_{\text {rad }}
$$

$$
a=0.5
$$

- Relative humidity $(\mathbf{r H})$. If the moisture balance is calculated, an adequate moisture buffer model should be used and described.

- Overheating period $\left(\tau_{O H}\right)$. It is the time period (in hours) during the occupancy period in which the indoor air temperature exceeds the cooling set point temperate $\left(25^{\circ} \mathrm{C}\right)$. In order to calculate it, ideal cooling has to be switched off. 


\subsection{Integration of renewables and storage}

Contribution of renewables to the total energy balance is considered in the non-renewable primary energy savings, see above. Additionally, the following KPIs might give some further insights:

Photovoltaic Panel (PV, BIPV, (BI)PVT):

- Self-consumption (SC), is defined as the total PV electricity the $\mathrm{N}$ households are able to consume by either instantaneous consumption, or battery storage, during the whole simulation time [12]. The Load Cover Factor (LCF) is defined as:

$$
L C F=S C / E_{\text {tot }}
$$

where $E_{\text {tot }}$ is the toal electric energy required by the building.

- Self-production (SP), is the load covered by instantaneous consumption of PV electricity or energy absorption from the batteries [12]. The Supply Cover Factor (SCF) is defined as:

$$
S C F=S P / P V
$$

where $P V$ is the total energy produced by the PV or PVT panel.

Solar thermal collectors (ST, BIST, (BI)PVT):

- The solar yield (SY) is defined as the total of the solar energy annually harvested per square meter of solar thermal collector.

- The solar fraction is the fraction of thermal load that can be covered with solar energy or, in other words, the amount of heat provided by the solar technology divided by the total energy required. In addition to the overall solar fraction (SFTот), separate yearly solar fractions for DHW (SF DHW) $_{\text {) }}$ and space heating (SF SH) are calculated. The solar fraction is

$$
S F=1-Q_{B U} / Q_{t o t}
$$

where $Q_{B U}$ is the thermal energy provided by the backup heater (BU) ad $Q_{\text {tot }}$ is the thermal energy of the reference system (without solar thermal).

\subsection{Indoor air quality}

Indoor air quality should be considered. Indoor air quality is measured in $\mathrm{CO}_{2}$ concentration. If there is no dedicated model, the following simplified approach can be used to evaluate the indoor air quality.

$\mathrm{CO}_{2}$ concentration can be calculated according to the standard EN 15251 [13] (see Eq. 5-12) and classified as reported in Table 5-4.

$$
C(t)=C_{0} e^{-\lambda t}+\left(P C_{a m b}+\frac{E}{\lambda V}\right)\left(1-e^{-\lambda t}\right)
$$

Where:

- $\quad C$ is the indoor concentration $\left[\mathrm{ppm}\right.$ or $\mu \mathrm{g} / \mathrm{m}^{3}$ ];

- $t$ is the time $[\mathrm{h}]$;

- $\quad P$ is the penetration factor [-] (set to 1$)$;

- $C_{a m b}$ is the outdoor concentration [ppm] (assumed to be constant and equal to $400 \mathrm{ppm}$ );

- $E$ is the mass emission rate $[\mu \mathrm{g} / \mathrm{h}] ;$

- $\lambda$ is the air change rate $\left[\mathrm{h}^{-1}\right]$;

- $\quad V$ is the zone volume $\left[\mathrm{m}^{3}\right]$.

The mass emission rate $(E)$ of $\mathrm{CO}_{2}$ from occupants is calculated as follows:

$$
E=\frac{n \cdot I R \cdot C_{\text {pers }}}{24}
$$


Where:

- $n$ is the number of persons in the room [-];

- $\quad I R$ is the daily inhalation rate $\left[\mathrm{m}^{3} /\right.$ day];

- $C_{\text {pers }}$ is the $\mathrm{CO}_{2}$ concentration in breath $\left[\mu \mathrm{g} / \mathrm{m}^{3}\right]$.

According to [14], the inhalation rate is assumed to be $16.3 \mathrm{~m}^{3} /$ day and the concentration in breath is $40000 \mathrm{ppm}$.

Table 5-4: Indoor environment quality design category defined in EN 15251 standard.

\begin{tabular}{c|c} 
Category & $\begin{array}{c}\mathrm{CO}_{2} \text { concentration } \\
\text { [ppm] }\end{array}$ \\
\hline I & 750 \\
II & 900 \\
III & 1200 \\
IV & $>1200$ \\
\hline
\end{tabular}

\subsection{Visual comfort}

Several metrics are in use for assessing the visual performance of daylighting systems. A recent report by [15] gives a comprehensive overview of the advantages and limitations of the various approaches. With reference to Solar Building Envelopes, three metrics are proposed as KPIs for the reference building: (continuous) daylight autonomy as daylight availability metric and luminance threshold and (simplified) daylight glare probability as daylight glare metrics. Additionally, one more daylight availability metric as well as one daylight glare metric are mentioned, which are used in further case studies.

- (Continuous) Daylight Autonomy cDA. The daylight autonomy $(D A)$ is defined as the percentage of occupied hours, where a given illuminance threshold can be achieved by daylight. While the Daylight Factor (DF) is defined just for a static (usually overcast) sky distribution, the DA-metric takes into account all sky conditions based on the local weather file. Typical thresholds are DA500 for work plane and DA300 for the space area. Compared to the conventional DA-specification, the continuous Daylight Autonomy (cDA) metric enables partial credits also for hours, when the illuminance value lies below the design threshold. For example, if an illuminance sensor reaches 400lux instead of the given 500lux, a credit of 0.8 is still given through the partial contribution. This additional definition of the metric is justified by field studies that indicate that illumination preferences vary between different occupants, which tend to work also at lower illuminance levels. Furthermore, the metric considers also lower daylight entries as a benefit for space illuminance

- Luminance threshold Lmax. The luminance level of a surface is a measure which represents the brightness of a surface - and therefore the risk to get glared. Based on a defined threshold for the maximum allowed luminance level on the inner façade, a reasonable evaluation for the risk of glare is therefore possible. Different thresholds have been published by different researchers in recent years; Nutek (2001): $2000 \mathrm{~cd} / \mathrm{m}^{2}$, Osterhaus (2002, 2009): $2500 \mathrm{~cd} / \mathrm{m}^{2}$, Wienold (2005): $6000 \mathrm{~cd} / \mathrm{m}^{2}$, Linney (2008): $2160 \mathrm{~cd} / \mathrm{m}^{2}$, Shin (2012): $5600 \mathrm{~cd} / \mathrm{m}^{2}$. Bartenbach proposes, based on DIN 12464-1, a mean luminance value $\leq 1000$ $\mathrm{cd} / \mathrm{m}^{2}$ and a maximum luminance valuef $\leq 3000 \mathrm{~cd} / \mathrm{m}^{2}$ for transparent façades.

- Daylight Glare Probability. The risk of glare discomfort is quantified using daylight glare probability (DGP) [16]. DGP is usually assessed based on an image describing the luminance distribution in the field of view (i.e. an HDR rendering or photo) using the software evalglare [17]. Areas of high luminance are detected as potential glare sources using an algorithm and their contribution to the overall DGP value is based on the luminance of the glare source, its position and size within the field of view, and the overall vertical illuminance at the point of the observer. Table 5-5 shows the categorization of DGP values in terms of the generally perceived degree of discomfort. To assess glare across an annual period, the degree of glare protection can be quantified by taking the share of occupied hours that a glare classification is exceeded (DGPe). Different glare protection levels are defined using a 5\% exceedance criterion [18]. To avoid discomfort glare for office-like spaces and achieve a minimum level of glare protection, the Daylight Glare Probability (DGP) for the main viewing direction should not exceed a value of 0.45 for $5 \%$ of the occupied time. As shown in Table 5-6, the new Standard EN17037 "Daylight in Buildings" gives requirements for annual DGP-thresholds $(0,35 / 0,4 / 0,45)$ connected to different glare protection levels (low/medium/high), which should not be exceed for more than $5 \%$ of the occupancy time [19]. 
Table 5-5: DGP glare discomfort classification [16]

\begin{tabular}{l|l} 
Glare category & Threshold \\
\hline Imperceptible & $<0.35$ \\
Perceptible & $0.35-0.40$ \\
Disturbing & $0.40-0.45$ \\
Intolerable & $>0.45$ \\
\hline
\end{tabular}

Table 5-6 Annual glare protection level classes [19]

\begin{tabular}{l|l} 
Glare protection level & DGP $_{\mathrm{e}<5 \%}$ \\
\hline High & 0.35 \\
Medium & 0.40 \\
Low & 0.45 \\
\hline
\end{tabular}

- Daylight Glare Probability simplified DGPs. DGPs approximates the daylight glare probability from vertical illuminance only for a particular point and viewing direction [20]. DGPs has been shown to be less robust than the more advanced DGP approach [21]. Both metrics use the same categorization (Table 5-5).

- Spatial Daylight Autonomy sDA. Another metric to express the annual daylight performance is the spatial daylight autonomy (sDA). This metric describes the annual sufficiency of ambient daylight levels in interior rooms. The sDA is defined as percentage of the task area that meets a minimum daylight illuminance level for a given fraction of operating hours per year, i.e. that meets a defined daylight autonomy level [22].

According to IES LM-83-12 [22] target values for the spatial daylight autonomy are:

○ $\quad$ SDA $300,50 \% \geq 55 \%$ : nominally acceptable daylight sufficiency;

○ $\quad$ SDA $300,50 \% \geq 75 \%$ : preferred daylight sufficiency.

\subsection{Economic calculation}

The economic analysis adopted in this work is based on the Equivalent Annual Cost (EAC), considering investment and running costs over a reference lifetime $(N)$. EAC is the annual cost of owning, operating, and maintaining an asset over its entire life, it allows comparing the cost-effectiveness of various assets that have unequal lifespans. Eq. 5-14 shows the calculation of the EAC:

$$
E A C=\frac{I C \cdot r}{1-(1+r)^{-N}}
$$

Where $r$ is the nominal interest rate $(3 \%), N$ the lifetime of the considered technology and IC is the investment cost plus the installation cost.

The total annual cost (TAC) can be calculated, for electrically driven systems, as:

$$
T A C=E A C+M C+O C
$$

Where $\mathrm{MC}$ is the yearly maintenance cost and $\mathrm{OC}$ represent the operative cost calculated multiplying the (FE) final electric energy by the $\left(e l_{\text {price }}\right)$ electricity price:

$$
O C=F E \cdot e l_{\text {price }}
$$


The electricity price can be assumed as $0.2 € / \mathrm{kWh}$ and an energy price escalation rate should be considered ( $2 \%)$. The period of consideration is $20 \mathrm{yrs}$, i.e. the electricity price is $0.25 € / \mathrm{kWh}$ in average over the consideration period of $\mathrm{T}=20 \mathrm{yrs}$.

A sensitivity analysis should be carried out varying the interest rate (e.g. $\pm 1 \%$ point from the default value), the investment cost (e.g. $\pm 20 \%$ ) and the electricity price (e.g. $\pm 20 \%$ ) in order to assess the sensitivity of the economic results to the input data.

Table 5-7 reports as example the investment, installation, maintenance costs and the technical lifetime for some commonly used technologies. The data for heat pump (HP) and photovoltaic panels (PV) are all taken from [23] except the investment cost of PV which is taken from [24] where mono-crystalline silicon PV are considered. The data for battery and LED are assumed considering the current price of different sellers. The battery is usually guaranteed for 10 years while LED for 50000 hours that correspond to a lifetime of 15 years.

Table 5-7. Investment costs, installation costs, maintenance costs for commonly used technologies

\begin{tabular}{|c|c|c|c|c|}
\hline Renovation measure & $\begin{array}{c}\text { Investment costs } \\
{[€]}\end{array}$ & $\begin{array}{c}\text { Installation costs } \\
{[€]}\end{array}$ & $\begin{array}{c}\text { Maintenance } \\
\text { costs }[€ / y]\end{array}$ & $\begin{array}{c}\text { Technical lifetime } \\
{[y]}\end{array}$ \\
\hline Split unit & $500[23]$ & 100 [23] & 16 [23] & 12 [23] \\
\hline PV (mono-crystalline silicon) & $2322[24]$ & 380 [23] & $34.2[23]$ & 20 [23] \\
\hline Battery (4.8 kWh) with Inverter & 4000 & 1400 & 0 & 10 \\
\hline LED light (8 luminaire) & 640 & 300 & 0 & 15 \\
\hline
\end{tabular}




\section{Simulation Platform}

Several validated simulation platforms can be used for the simulation of a building and its energy system (e.g. TRNSYS, IDA ICE, EnergyPlus, Matlab/Simulink, Modelica, etc...). The version of the used simulation tool and special setting should be indicated.

Design or pre-design calculation or simplified simulation tools (such as e.g. PHPP) or specific pre-design simulation tools (such as DALEC or Fener), which are useful to understand the behaviour of buildings and optimize the performance already in the early design process of buildings, will be tested against the results of the detailed simulation.

\subsection{Platform overview and modelling features}

Different tools, used for the simulation of the reference office cell, are analysed in [25]:

- EnergyPlus ${ }^{\mathrm{TM}}(\mathrm{EP})$ is a whole building energy simulation program that engineers, architects, and researchers use to model both energy consumption for heating, cooling, ventilation, lighting and plug and process loads and water use in buildings [26];

- $\quad$ TRNSYS (TRN) is a transient system simulation program based on a component approach with modular structure. The TRNSYS library includes a detailed multizone building model and components for HVAC systems, renewable energy systems, etc. [27];

- $\quad$ Simulink carnotUIBK (SIM_IBK) is a Matlab/Simulink library, compatible with CARNOT Toolbox, developed by the University of Innsbruck, based on object-oriented programming of a parameterized building model [28];

- Simulink ALMAbuild (SIM_BO) is a Matlab/Simulink library, compatible with CARNOT Toolbox, developed by the University of Bologna where a user develops a building model by means of a series of Graphical User Interfaces [29];

- $\quad$ MODELICA (MOD) is a non-proprietary, object-oriented, equation based language to conveniently model complex physical systems, with a wide open source library (in this case the LBNL Buildings library is used) [30];

- $\quad$ DALEC (DAL) is a free web tool developed by Bartenbach, University of Innsbruck and Zumtobel. The main focus is on combined thermal and lighting building simulations in early design phases [31];

- $\quad$ FENER (FEN) is a web based platform for Integrated daylight, glare and energy evaluation of fenestration technologies [32];

- $\quad$ PHPP Passive House Planning Package is a quasi steady state calculation tool, developed as spread sheet, for the use of architects and planning experts [33].

The different tools implement models with different level of detail and approach the numerical solution of the building system with different equations.

\subsection{Platform modelling features}

Table 6-1 reports the physical models used by the different tools for the calculation of the room balance and the time step used in the numerical simulations of the reference office building in [25]. The two star node model includes a convective node (representing the thermal capacity of the air) and a radiative node (the long-wave radiative exchange between the surfaces is modelled using the star network).

In the simplified calculation mode, TRN implements a star network where an artificial temperature node (Tstar) is used to consider the parallel energy flow from the inside wall surface to the zone air by convection and the longwave radiation exchange between the surfaces.

EP uses a grey interchange model (ScriptF) involving an approximation of direct view factors for the radiative exchange between surfaces.

MOD implements a more detailed model for the radiative exchange based on net radiation exchange approach [34]. DAL model is based on the Standard ISO 13790:2008 [35] where the room heat balance is solved considering three nodes and both the air temperature and mean radiant temperature are calculated. The nodes are connected between each other by means of specific coupling conductance defined by the standard. The whole thermal capacity of walls and air volume is connected to the node representing the mean radiant temperature. 
PHPP is a quasi-steady state tool that calculates losses and gains considering a fixed set point temperature. It performs two different balances by using the two set point temperatures for winter and summer.

Each tool performs the simulation using different time steps and, in particular: SIM_IBK and SIM_BO use variablestep solvers, which vary the step size during the simulation depending on the required numerical accuracy and the solver. All the other tools perform the calculation with a constant time step as reported in Table 6-1. The definition of the time step influences the run time and the accuracy of the results.

Table 6-1: Model of the room heat balance and simulation time step used for the simulation of the reference office cell

\begin{tabular}{c|cc} 
& Surface to zone heat transfer & Time step \\
\hline EP & Radiative and conv. node & Const.: $15 \mathrm{~min}$ \\
TRN & Star node model & Const.: $60 \mathrm{~min}$ \\
SIM_IBK & Two star node model & Var.: $\max 10 \mathrm{~min}$ \\
SIM_BO & Two star node model & Var.: $\max 10 \mathrm{~min}$ \\
DAL & Standard ISO 13790 & Const.: $60 \mathrm{~min}$ \\
MOD & Radiosity and conv. node & Const.: $15 \mathrm{~min}$ \\
PHPP & Steady state balance & Monthly \\
\hline
\end{tabular}

Table 6-2 reports the model used for the wall structure in each tool [25]. EP and TRN model the opaque structure with the transfer function method, whereas both Simulink libraries and MOD are based resistance-capacity $(R-C)$ method. DAL and PHPP implement a simplified model of the walls, based on the overall heat transfer coefficient $(\mathrm{H})$ of the external structures.

\begin{tabular}{c|c}
\multicolumn{2}{c}{ Table 6-2: Model of the walls. } \\
Wall model
\end{tabular}

Different window models are implemented in the analysed tools [25], in particular, EP, TRN, SIM_BO and MOD perform an energy balance over each pane of the window while DAL, SIM_IBK and PHPP are based on a simplified window thermal model where the transmission losses of the window are calculated by using a constant heat transfer coefficient. An additional layer representing the shading system is involved in the thermal balance of the window only in EP and MOD.

Gains from solar radiation are computed differently in each tool. EP, TRN, SIM_BO and MOD consider how solar radiation is absorbed by each pane of the window, which increases the pane temperature, and how it influences convective and radiative exchange.

In the presented heat balances for EP, SIM_BO and MOD solar gains are defined as directly transmitted radiation (convective and radiative gains from the inner pane do contribute to the room heat balance but they are not reported as 'solar gains' in the presented balances). The calculation of the solar gain in DAL is based on an angular dependent $g$-value of the façade dependent on the sun position, SIM_IBK calculation is based on an angular dependent $g$-value of the glazing system, dependent on the sun position. Depending on the definition of the solar gain (total or only transmitted part), also the definition of the transmission losses is different. When only the directly transmitted part of the solar radiation is reported as solar gain, the transmission loss is represented by the exchange between the internal side of the window and the thermal zone $\left(\dot{Q}_{i n t, p 2}\right.$ in Figure 6-1). Contrariwise, when the total solar gain is reported (including absorbed solar radiation reemitted to the inside), the transmission losses are calculated as $\left(\dot{Q}_{t r, p 1-p 2}\right.$ in Figure 6-1). 


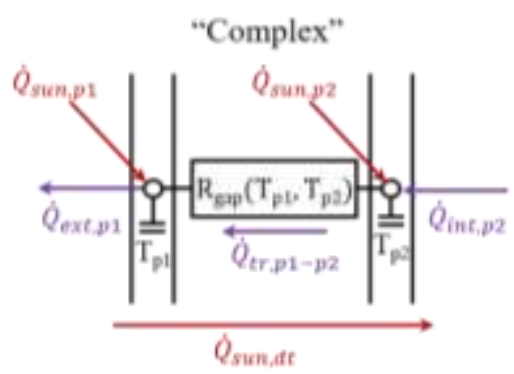

Figure 6-1: Sketch of the Complex window model.

The models used to predict the diffuse radiation on a tilted surface can be based on either isotropic or anisotropic sky models. All the tools except for DAL calculate the diffuse radiation on a tilted surface with anisotropic sky models while DAL uses an isotropic sky model.

The profiles for occupancy, appliances and lighting described in section 3.3.2 could not be implemented in DAL and PHPP. In DAL a constant internal gain of $8.79 \mathrm{~W} / \mathrm{m}^{2}$ from 8 a.m. to 19 p.m. is considered while in PHPP a constant internal gain of $6.5 \mathrm{~W} / \mathrm{m}^{2}$ is considered.

With regard to the ventilation system, EP, TRN, SIM_IBK, SIM_BO and MOD calculate the ventilation rate, bypass control and infiltration losses as described in 3.3.3 while DAL uses a constant energy equivalent air exchange rate that takes into account the infiltration and energy effective air exchange rate. The additional ventilation losses due to activation of the bypass are modelled as window/night ventilation. PHPP considers ventilation losses using a constant equivalent air exchange rate. A different rate is used, for summertime and wintertime, which accounts for the frequency with which the bypass is activated in that period. These equivalent air exchanges are calibrated in order to match the ventilation losses calculated by SIM_IBK.

The shading control system is modelled based on a $120 \mathrm{~W} / \mathrm{m}^{2}$ beam direct solar radiation threshold as described in 3.3.4 for all the tools except for the PHPP, where it is only possible to set a constant value for the summer and winter time.

Table 6-3: Internal gain profile and ventilation rate.

\begin{tabular}{l|ccc}
\multicolumn{1}{c}{ Internal Gain } & Ventilation rate/control & Shading control \\
\hline EP & Profile & Profile/Dynamic ctr. & Dynamic \\
TRN & Profile & Profile/Dynamic ctr. & Dynamic \\
SIM_IBK & Profile & Profile/Dynamic ctr. & Dynamic \\
SIM_BO & Profile & Profile/Dynamic ctr. & Dynamic \\
DAL & Constant & Constant & Dynamic \\
MOD & Profile & Profile/Dynamic ctr. & Dynamic \\
PHPP & Constant & Constant & Constant \\
\hline
\end{tabular}

\section{Conclusions}

This report (DC.1) provides the description of the simulation model (office reference cell) used in IEA SHC Task 56 to simulate the performance of different solar envelope technologies on building level. The simulation results of different case studies are reported in DC.2. 


\section{Literature Reference}

[1] IBPSA-USA, Building Energy Modeling book - BEMBook, Rocky Mountain Institute \& Ashrae, 2012.

[2] SIA 2024:2015, Raumnutzungsdaten für di Energie- und Gebäudetechnik, Zurich, Switzerland.

[3] EN ISO 7730:2006-5, Ergonomics of the thermal environment. Analytical determination and interpretation of thermal comfort using calculation of the PMV and PPD indices and local thermal comfort criteria., Geneve, Switzerland: International Organisation for Standardisation, 2006.

[4] iNSPiRe, Development of Systemic Packages for Deep Energy Renovation of Residential and Tertiary Buildings including Envelope and Systems., 2013.

[5] University of Wisconsin-Madison, „TRNSYS 17,“ University of Wisconsin-Madison, Madison, WI , 2017.

[6] Meteonorm V 7.2.4, "Meteonorm - global meteorological database," [Online]. Available: https://meteonorm.com/. [Accessed 1402 2019].

[7] International Organisation for Standardisation, ISO 52000-1:2016. Energy performance of buildings Overarching EPB assessment - Part 1: General framework and procedures, 2016.

[8] EnEV, "Nichtamtliche Lesefassung der EnEV 2014," [Online]. Available: http://www.enev-2014.info/enevnicht-amtliche-fassung-16-10-13-aenderungen.pdf. [Accessed 2211 2019].

[9] Österreichisches Institut für Bautechnik, OIB-6 Richtlinie 6, Energieeinsparung und Wärmeschutz, 2011, update 2015.

[10] ENTSO-E, "Transparency Platform," [Online]. Available: https://transparency.entsoe.eu. [Accessed 2211 2019].

[11] F. Ochs und G. Dermentzis, „Evaluation of Efficiency and Renewable Energy Measures Considering the Future Energy Mix," in 7th International Building Physics Conference, Syracuse, NY,USA, 2018.

[12] M. Secchi und G. Barchi, „Peer-to-Peer electricity sharing: maximising PV self-consumption through BESS control strategies," in EEEIC, 2019.

[13] EN 15251, EN 15251:2008 Indoor environmental input parameters for design and assessment of energy performance of buildings addressing indoor air quality, thermal environment, lighting and acoustics.

[14] U.S. Environmental Protection Agency, Exposure Factors Handbook, Edition (Final Report) ed., Washington, DC, 2011.

[15] IEA SHC Task 50, „Advanced Lighting for Retrofitting Buildings. Subtask C Report C.4 Energy audit and inspection procedures, " 2017.

[16] J. Wienold and J. Christoffersen, "Evaluation methods and development of a new glare prediction model for daylight environments with the use of CCD cameras," Energy and Buildings, vol. 38, no. 7, pp. 743-757, 2006.

[17] J. Wienold, "evglare version 2.0, 15th International Radiance Workshop, Padova, Italz, September 2016," [Online]. Available: https://www.radiance-online.org/community/workshops/2016-padua/presentations/211Wienold-Evalglare2.0.pdf. [Accessed 1002 2020].

[18] C. 14501, Blinds and shutters - Thermal and visual comfort - Performance characteristics and classification, 2005.

[19] CEN 17037, Daylight in Buildings. 
[20] J. Wienold, Daylight Glare in Offices, Freiburg/Brsg: Fraunhofer ISE, 2010.

[21] J. Wienold, "Cross-validation and robustness of daylight glare metrics," Lighting Research \& Technology, vol. 51, no. 7, 2019.

[22] IES LM-83-12, Approved Method: IES Spatial Daylight Autonomy (sDA) and Annual Sunlight Exposure (ASE), Illuminating Engineering Society, 2013.

[23] M. Gustafsson, C. Dipasquale, S. Poppi, A. Bellini, R. Fedrizzi, C. Bales, F. Ochs, M. Sié and S. Holmberg, "Economic and environmental analysis of energy renovation packagesfor European office buildings," Energy and Buildings, vol. 148, pp. 155-165, 2017.

[24] F. Ascione, N. Bianco, G. Maria Mauro and G. Peter Vanoli, "A new comprehensive framework for the multiobjective optimization of building energy design: Harlequin," Applied Energy, vol. 241, pp. 331-361, 2019.

[25] M. Magni, F. Ochs, P. Bonato, M. D'Antoni, D. Geisler-Moroder, S. de Vries, R. Loonen, A. Maccarini, A. Afshari und T. Calabrese, „Comparison of Simulation Results for an Office Building Between Different BES Tools - The Challenge of Getting Rid of Modeller Influence and Identifying Reasons for Deviations," in Bilding Simulation Conference, Rome, 2019.

[26] D. B. Crawley, L. K. Lawrie, C. O. Pedersen and F. C. Winkelmann, "EnergyPlus: Energy Simulation Program," ASHRAE Journal, vol. 42, pp. 49-56, 2000.

[27] S. Klein , W. Beckman, J. Mitchell, J. Duffie, N. Duffie, T. Freeman und et al., „TRNSYS 17, TRaNsient SYstem Simulation program.," University of Wisconsin, Madison, WI, USA, 1979.

[28] D. Siegele, E. Leonardi and F. Ochs, "A new MATLAB Simulink Toolbox for Dynamic Building Simulaiton with BIM and Hardware in the Loop compatibility," in Building Simulation, Rome, 2019.

[29] J. P. Campana , G. L. Morini und M. Magni, „The benchmark of the SIMULINK open library ALMABuild for dynamic modelling of buildings, " in 16th International Conference on Sustainable Energy Technologies - SET 2017, Bologna, 2017.

[30] M. Wetter, W. Zuo und S. Nouidui, „Modeling of Heat Transfer in Rooms in the Modelica "Buildings" Library," in Building Performance Simulation conference, Sydney (AUS), 2011.

[31] M. Werner, D. Geisler-Moroder, B. Junghans, O. Ebert and W. Feist, "DALEC - a novel web tool for integrated day- and artificial light and energy calculation," Journal of Building Performance Simulation, vol. 10, no. 3, pp. 344-363, 2016.

[32] Fraunhofer Institute for Solar Energy Systems ISE, "Fener," [Online]. Available: https://fenerwebport.ise.fraunhofer.de/. [Accessed 0604 2020].

[33] W. Feist, "PHPP - Passive House Planning Package," [Online]. Available: https://passivehouse.com/04_phpp/04_phpp.htm. [Accessed 1601 2019].

[34] M. Wetter, W. Zuo und S. Nouidui, „Modeling of Heat Transfer in Rooms in the Modelica "Buildings" Library, in Proceedings of Building Simulation, Sydney, 2011.

[35] ISO 13790:2008, Energy performance of buildings - Calculation of energy use for space heating and cooling. 


\section{Appendix}

\section{A. 1 Predicting monthly primary energy conversion factors}

There is a need for an appropriate evaluation method for comparing and ranking different passive and active technologies on micro- and macro- economic scale. National conversion factors for PE/CO2 differ significantly between different countries and also between the EU member states and are subject to change. For example, the PE factor for electricity is 1.8 in Germany (EnEV 2014 Annex 1 section 2.1 .1 [8]) since 2016 (2.4 before), Austria $f_{P E n o n-R E} 1.02$ since 2019, f fEnon-RE 1.32 since 2015, 2.15 before. Seasonal variations are not considered at all.

For the electricity mix, the share of renewables within the time frame of consideration (e.g. 20 years) should be included and not as usually done the current (or past) status. A significantly increased share of RE electricity can be expected in the near future in particular in summer (PV), while in winter only a moderate increase is likely, unless there is a significant further extension of wind power or seasonal storage capacities are strongly build up.

If a large number of buildings use heat pumps (HP) for space heating and DHW preparation and produce electricity with on-site PV, both, the purchased electric energy and the share of renewables in the electricity mix depend on each other. Electricity that is used on site is not available in the grid and an increased share of fossil fuels in the energy mix have to be considered. PV electricity sold to the grid will replace fossil fuels more likely in winter, spring and autumn than in summer. Thus, a model for the $\mathrm{PE} / \mathrm{CO}_{2}$ conversion factor of the electricity mix needs to consider $\mathrm{RE}$ availability and the load curve. A possible approach of balancing $\mathrm{PE}$ demand (and $\mathrm{CO}_{2}$ emissions) of a building with onsite RE generation is shown schematically in Figure A-1 Solar thermal (ST) energy is used to reduce the energy demand (heating, DHW + storage and distribution losses) that has to be covered by e.g. a heat pump (HP). Onsite PV can be used directly for appliances and auxiliary energies or to drive the HP. For higher own consumption, a (battery) storage is required, which is subject to losses.

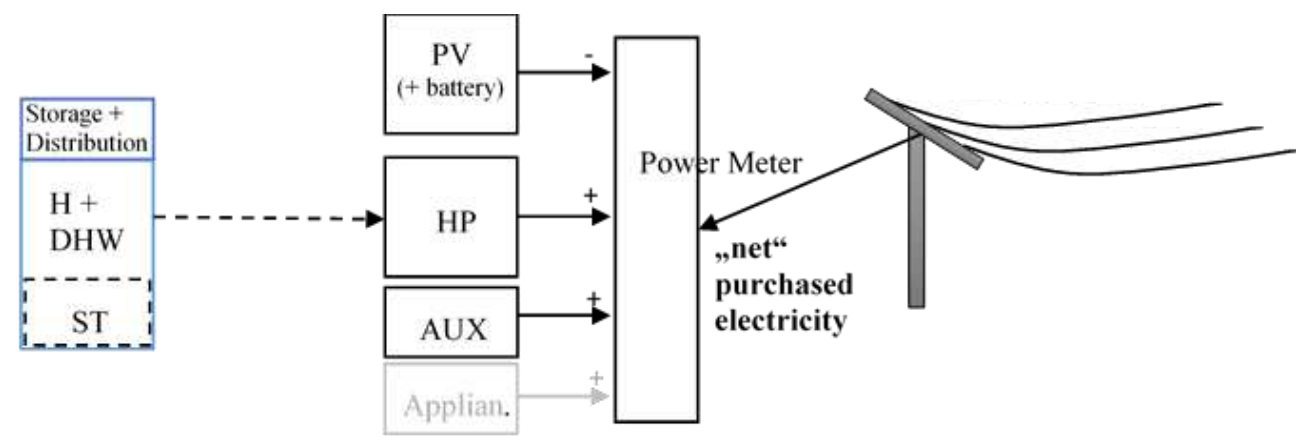

Figure A-1: Possible approach for the calculation of the monthly net energy balance with heating $(\mathrm{H})$ and domestic hot water (DHW) demand covered partly by ST; the remaining demand is covered by a heat pump (HP), which is partly powered by onsite PV, the remaining electricity demand for the HP, auxiliary energies (and appliances) is covered by the grid with volatile shares of renewable electricity

A monthly evaluation based on monthly primary energy factors is proposed, which can be used to calculate a more representative environmental impact of different efficiency and RE measures. The specific primary energy ePE is calculated for each month $(i)$

$$
e_{P E}=\sum f_{P E, i} \cdot w_{e l, i}
$$

where $f_{P E, i}$ is the primary energy conversion factor for each month $(i)$ considering the energy mix in each month and $w_{e l, i}$ is the specific electric energy purchased in each month, see Figure A-2.

In two scenarios (A and B) with different shares of hydro, wind, PV and fossil energy, the PE conversion factor were calculated on monthly basis using e.g. the PE conversion factors shown in Figure A-2 and Table A-1.

$$
f_{P E}=f_{P E, h y d} \cdot \frac{w_{e l, h y d}}{w_{e l}}+f_{P E, \text { wind }} \cdot \frac{w_{e l, w i n d}}{w_{e l}}+f_{P E, P V} \cdot \frac{w_{e l, P V}}{w_{e l}}+f_{P E, \text { fos }} \cdot \frac{w_{e l, f o s}}{w_{e l}}
$$

Table A-1. $\mathrm{CO}_{2}$-emissions and primary energy (PE) conversion factors of fossil and renewable electric energy sources, acc. to DVGW 2016 
Source

Electricity Mix Germany

Electricity from Gas

Hydro

Wind

PV (off-site)

*assumptions
$\frac{\mathrm{CO}_{2} /[\mathrm{g} / \mathrm{kW}}{520}$

432

2.4

$0.01^{*}$

0.05

9

56

0.1
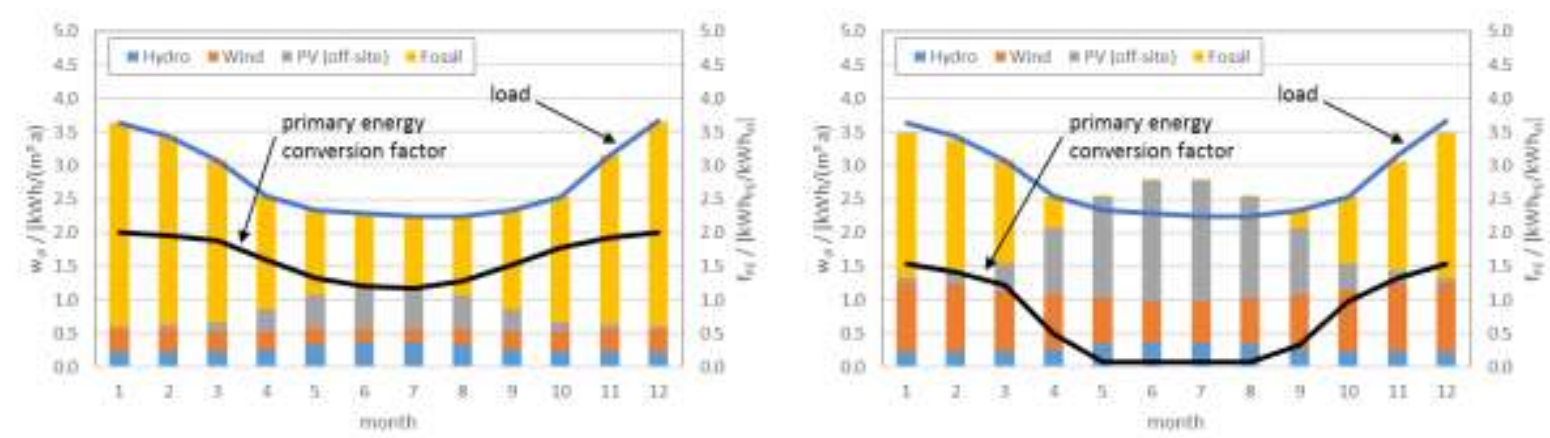

Figure A-2: Monthly share of renewables (hydro, wind, PV, fossil) and corresponding PE conversion factor, example of a PH with a HP for heating and DHW supply with (A) a share of $10 \%$ hydro, $10 \%$ wind, $10 \% \mathrm{PV}$ and $70 \%$ fossil, and (B) a share of $10 \%$ hydro, $30 \%$ wind, $30 \% \mathrm{PV}$ and $30 \%$ fossil in the electricity mix

Table A-2: Monthly PE conversion factors see Figure A-2 and PE conversion factors acc. to Table A-1

\begin{tabular}{l|lllllllllllll}
\multicolumn{1}{l}{} & Jan & Feb & Mar & Apr & May & Jun & Jul & Aug & Sep & Oct & Nov & Dec & av. \\
\hline A: $\mathbf{1 0 - 1 0 - 1 0}$ & 2.01 & 1.96 & 1.89 & 1.60 & 1.33 & 1.20 & 1.18 & 1.28 & 1.53 & 1.78 & 1.92 & 2.01 & 1.6 \\
B: $\mathbf{1 0 - 3 0 - 3 0}$ & 1.53 & 1.42 & 1.23 & 0.50 & 0.08 & 0.08 & 0.08 & 0.08 & 0.33 & 0.98 & 1.33 & 1.54 & 0.8
\end{tabular}




\section{A. 2 Detailed properties of the windows assemblies used in the reference office building}

\section{Rome}

WINDOW 4.1 DOE-2 Data File : Multi Band Calculation (Unit System: SI)

Window ID: 3304 (TRNSYS 15 WINDOW LIB)

Description: double glazing with Argon gap and low-SHGC coating, 6/16/6

Tilt: 90.0

Table A-3: Gap properties of the Rome window assembly

\begin{tabular}{cccccccccc} 
Gap & Thick & Cond & dCond & Vis & dVis & Dens & dDens & Pr & dPr \\
\hline Argon & 16.0 & 0.0162 & 5.0 & 2.11 & 6.3 & 1.78 & -0.006 & 0.68 & 0.00066
\end{tabular}

Table A-4: Optical properties of the Rome window assembly

\begin{tabular}{c|ccccccccccc} 
Angle & $\mathbf{0}$ & $\mathbf{1 0}$ & $\mathbf{2 0}$ & $\mathbf{3 0}$ & $\mathbf{4 0}$ & $\mathbf{5 0}$ & $\mathbf{6 0}$ & $\mathbf{7 0}$ & $\mathbf{8 0}$ & $\mathbf{9 0}$ & Hemis \\
\hline Tsol & 0.260 & 0.261 & 0.257 & 0.251 & 0.243 & 0.229 & 0.200 & 0.145 & 0.066 & 0.000 & 0.214 \\
Abs1 & 0.470 & 0.474 & 0.480 & 0.482 & 0.480 & 0.477 & 0.477 & 0.460 & 0.351 & 0.001 & 0.464 \\
Abs2 & 0.052 & 0.053 & 0.053 & 0.054 & 0.055 & 0.055 & 0.053 & 0.047 & 0.033 & 0.000 & 0.051 \\
Rfsol & 0.218 & 0.212 & 0.210 & 0.213 & 0.222 & 0.238 & 0.269 & 0.348 & 0.550 & 0.999 & 0.260 \\
Rbsol & 0.259 & 0.254 & 0.252 & 0.252 & 0.257 & 0.271 & 0.306 & 0.393 & 0.582 & 1.000 & 0.297 \\
Tvis & 0.659 & 0.662 & 0.653 & 0.641 & 0.625 & 0.592 & 0.518 & 0.377 & 0.176 & 0.000 & 0.550 \\
Rfvis & 0.119 & 0.112 & 0.109 & 0.112 & 0.124 & 0.147 & 0.192 & 0.294 & 0.523 & 0.999 & 0.176 \\
Rbvis & 0.154 & 0.148 & 0.146 & 0.150 & 0.164 & 0.191 & 0.252 & 0.389 & 0.647 & 1.000 & 0.229 \\
SHGC & 0.333 & 0.336 & 0.332 & 0.327 & 0.320 & 0.306 & 0.275 & 0.214 & 0.116 & 0.000 & 0.287
\end{tabular}

Table A-5: Properties of the panes involved in the Rome window assembly

\begin{tabular}{c|cc} 
Layer ID\# & 9047 & 9026 \\
\hline Emis Front & 0.840 & 0.838 \\
Emis Back & 0.110 & 0.838 \\
Thickness $(\mathbf{m m})$ & 6.0 & 6.0 \\
Cond $\left(\mathrm{W} / \mathrm{m}^{2}-\mathrm{C}\right)$ & 150.0 & 150.0
\end{tabular}




\section{Stuttgart}

WINDOW 4.1 DOE-2 Data File : Multi Band Calculation (Unit System: SI)

Window ID: 2001 (TRNSYS 15 WINDOW LIB)

Description: double glazing with Argon gap and low-e coating, 4/16/4

Tilt: 90.0

Table A-6: Gap properties of the Stuttgart window assembly

\begin{tabular}{cccccccccc} 
Gap & Thick & Cond & dCond & Vis & dVis & Dens & dDens & Pr & dPr \\
\hline Argon & 16.0 & 0.0162 & 5.0 & 2.11 & 6.3 & 1.78 & -0.006 & 0.68 & 0.00066
\end{tabular}

Table A-7: Optical properties of the Stuttgart window assembly

\begin{tabular}{c|ccccccccccc} 
Angle & $\mathbf{0}$ & $\mathbf{1 0}$ & $\mathbf{2 0}$ & $\mathbf{3 0}$ & $\mathbf{4 0}$ & $\mathbf{5 0}$ & $\mathbf{6 0}$ & $\mathbf{7 0}$ & $\mathbf{8 0}$ & $\mathbf{9 0}$ & Hemis \\
\hline Tsol & 0.426 & 0.428 & 0.422 & 0.413 & 0.402 & 0.380 & 0.333 & 0.244 & 0.113 & 0.000 & 0.354 \\
Abs1 & 0.118 & 0.118 & 0.120 & 0.123 & 0.129 & 0.135 & 0.142 & 0.149 & 0.149 & 0.000 & 0.132 \\
Abs2 & 0.190 & 0.192 & 0.198 & 0.201 & 0.200 & 0.199 & 0.199 & 0.185 & 0.117 & 0.000 & 0.191 \\
Rfsol & 0.266 & 0.262 & 0.260 & 0.262 & 0.269 & 0.286 & 0.326 & 0.422 & 0.621 & 1.000 & 0.314 \\
Rbsol & 0.215 & 0.209 & 0.207 & 0.210 & 0.219 & 0.237 & 0.272 & 0.356 & 0.560 & 0.999 & 0.260 \\
Tvis & 0.706 & 0.710 & 0.701 & 0.688 & 0.670 & 0.635 & 0.556 & 0.403 & 0.188 & 0.000 & 0.590 \\
Rfvis & 0.121 & 0.115 & 0.114 & 0.118 & 0.132 & 0.163 & 0.228 & 0.376 & 0.649 & 1.000 & 0.203 \\
Rbvis & 0.103 & 0.096 & 0.093 & 0.096 & 0.108 & 0.132 & 0.179 & 0.286 & 0.520 & 0.999 & 0.162 \\
SHGC & 0.589 & 0.593 & 0.591 & 0.586 & 0.574 & 0.551 & 0.505 & 0.405 & 0.218 & 0.000 & 0.518
\end{tabular}

Table A-8: Properties of the panes involved in the Stuttgart window assembly

\begin{tabular}{|c|c|c|}
\hline Layer ID\# & 9052 & 9065 \\
\hline Emis Front & 0.840 & 0.140 \\
\hline Emis Back & 0.840 & 0.840 \\
\hline Thickness (mm) & 4.0 & 4.0 \\
\hline Cond $\left(\mathrm{W} / \mathrm{m}^{2}-\mathrm{C}\right)$ & 225.0 & 225.0 \\
\hline
\end{tabular}




\section{Stockholm}

WINDOW 4.1 DOE-2 Data File : Multi Band Calculation (Unit System: SI)

Window ID: 2206 (TRNSYS 15 WINDOW LIB)

Description: double glazing with Kripton gap and low-e coating, 4/16/4

Tilt: 90.0

Table A-9: Gap properties of the Stockholm window assembly

\begin{tabular}{cccccccccc} 
Gap & Thick & Cond & dCond & Vis & dVis & Dens & dDens & Pr & dPr \\
\hline Krypton & 16.0 & 0.00860 & 2.800 & 2.280 & 7.500 & 3.740 & -0.0137 & 0.660 & 0.00002
\end{tabular}

Table A-10: Optical properties of the Stockholm window assembly

\begin{tabular}{c|ccccccccccc} 
Angle & $\mathbf{0}$ & $\mathbf{1 0}$ & $\mathbf{2 0}$ & $\mathbf{3 0}$ & $\mathbf{4 0}$ & $\mathbf{5 0}$ & $\mathbf{6 0}$ & $\mathbf{7 0}$ & $\mathbf{8 0}$ & $\mathbf{9 0}$ & Hemis \\
\hline Tsol & 0.462 & 0.465 & 0.458 & 0.448 & 0.436 & 0.412 & 0.360 & 0.263 & 0.121 & 0.000 & 0.384 \\
Abs1 & 0.114 & 0.114 & 0.116 & 0.120 & 0.125 & 0.132 & 0.139 & 0.139 & 0.139 & 0.000 & 0.128 \\
Abs2 & 0.186 & 0.188 & 0.195 & 0.199 & 0.198 & 0.197 & 0.199 & 0.186 & 0.118 & 0.000 & 0.189 \\
Rfsol & 0.237 & 0.232 & 0.231 & 0.233 & 0.241 & 0.260 & 0.303 & 0.406 & 0.614 & 1.000 & 0.289 \\
Rbsol & 0.179 & 0.172 & 0.170 & 0.173 & 0.183 & 0.202 & 0.239 & 0.328 & 0.542 & 0.999 & 0.227 \\
Tvis & 0.749 & 0.754 & 0.743 & 0.730 & 0.711 & 0.674 & 0.589 & 0.428 & 0.200 & 0.000 & 0.626 \\
Rfvis & 0.121 & 0.115 & 0.114 & 0.118 & 0.132 & 0.163 & 0.228 & 0.376 & 0.649 & 1.000 & 0.203 \\
Rbvis & 0.109 & 0.102 & 0.099 & 0.102 & 0.115 & 0.140 & 0.188 & 0.296 & 0.529 & 0.999 & 0.170 \\
SHGC & 0.632 & 0.636 & 0.635 & 0.629 & 0.616 & 0.592 & 0.542 & 0.434 & 0.232 & 0.000 & 0.557
\end{tabular}

Table A-11: Properties of the panes involved in the Stockholm window assembly

\begin{tabular}{|c|c|c|}
\hline Layer ID\# & 9052 & 9065 \\
\hline Emis Front & 0.840 & 0.060 \\
\hline Emis Back & 0.840 & 0.840 \\
\hline Thickness (mm) & 4.0 & 4.0 \\
\hline Cond $\left(\mathrm{W} / \mathrm{m}^{2}-\mathrm{C}\right)$ & 225.0 & 225.0 \\
\hline
\end{tabular}

